Izvorni znanstveni rad

DOI: $10.17234 /$ Croatica.41.4

UDK: 821.163.42-13.09Vetranović, M.

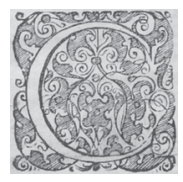

\title{
PRIČUDNO ČUDO I ZVIEREN'JE RAZLIKO: PRILOG HODOČAŠĆIMA PO VETRANOVIĆEVU PILIGRINU
}

\author{
Morana Čale \\ Filozofski fakultet Sveučilišta u Zagrebu \\ mčale@ffzg.hr
}

Krećući od nekoliko radova koje je Dunja Fališevac posvetila Vetranovićevu Piligrinu članak istražuje mogućnost da se taj nedovršeni alegorijski spjev, osim u sklopu religiozne i platonističke alegorijske književne tradicije, promotri sa stajališta pretpostavke o dvostrukoj kodiranosti teksta, tj. o njegovoj usporednoj pripadnosti oprečnoj žanrovsko-tematskoj crti, obilježenoj nadasve renesansnom obnovom Lukijanove i Apulejeve baštine. Za procvat menipske satire i tzv. lukijanizma u Italiji 15. stoljeća među najzaslužnijima je Leon Battista Alberti, čije djelo se u članku uključuje među dosad spominjane, a s Albertiem povezane talijanske uzore Piligrina. Hibridnost i mozaičnost Vetranovićevih tekstualnih strategija, kao i usredotočenost na temu pretvorbe i onostranog putovanja, pripisuju se pjesnikovoj naklonosti prema anticiceronijanskim humanistima, zanimanju za komiku i satiru te djelomice njegovu prijateljstvu s Marinom Držićem. S lukijanskim se temama i pripovjednim, odnosno dijaloškim tehnikama prepleće dvojaka, platonistička i satirička, renesansna fortuna Apulejevih Metamorfoza (Zlatnog magarca). Na temelju usporedbe Piligrina s Apulejevim romanom, a zatim i s jednim od njegovih samosvojnih talijanskih nasljednika, Machiavellievim kratkim spjevom Magarac (1517), iznosi se teza o još nezamijećenim odjecima tih dvaju tekstova u Vetranovićevu spjevu.

Ključne riječi: Vetranovićev Piligrin, Danteova Komedija, neoplatonizam i moralističko čitanje Homera i Ovidija, Lukijan iz Samosate, Leon Battista Alberti, anticiceronijanizam, Erazmo, Ariosto, Poliziano, Apulejeve Metamorfoze ili Zlatni magarac, Magarac Niccolòa Machiavellia, pretvorba, alegorija, parodija, menipska satira, pastiš, travestija 
U jednome od tekstova u kojima se bavi Piligrinom, potičući svoje kolege i učenike da se nanovo posvete problemima genealogije i tumačenja zagonetnoga Vetranovićeva djela te razmatrajući uvide prethodnih istraživanja, Dunja Fališevac upozorava da, naprama svojim neosporno važnim srednjovjekovnim uzorima alegorijskih književnih putovanja, poput Danteove Komedije i Deguilevilleovih peregrinacijskih pripovijesti, nedovršeni spjev hrvatskoga autora tvori "pomak od srednjovjekovnih peregrinskih tema o čišćenju od tjelesne i putu duhovnoj ljubavi”" (Fališevac 1989: 107). Neke je od takvih pomaka u smjeru oponašanja Vetranoviću kronološki bližih humanističkih i renesansnih talijanskih autora, kakvi su Poliziano, Ariosto i Sannazzaro, ${ }^{1}$ uz bok antičkima, nezaobilaznome Ovidiju i Teokritu, ${ }^{2}$ uočio Milorad Medini (usp. Medini 1902: 168, 204, 234) koji je međutim sve Vetranovićeve posudbe te vrste ocijenio neprimjerenima kako domaćim

1 Iako Medini ne objašnjava o kojim je motivima točno riječ, možemo pretpostaviti što ima na umu u vezi s Polizianom (npr. Piligrin zaneseno slijedi "ovčicu" koja se pretvori u platonički lijepu i kreposnu djevicu usp. P 502, 551-554, 583-584, kao što u Stancama Iulio-Giuliano slijedi košutu koja se pretvori u Simonettu, a protagonist je nazove svojom Dijanom; prije nego što ustvrdi kako se zavjetovala da služi Dijani, Vetranovićeva djevica izjavljuje da se rodila iz vode, usp. P 621-622, dok Polizianova Simonetta kaže da se - s čudom svoje ljepote, kakvome se i ovom prilikom divi Piligrin, usp. npr. $P$ 555, 617, 666 - rodila iz krila božice Venere, čije se pak rođenje iz morske pjene u Poliziana smatra nadahnućem Botticellieve Primavere, usp. npr. Doglio 1983), Ariostom (prije svega, motiv Orlandove mahnitosti koja se pretvara u Piligrinove odbjegle misli i njegovo stalno stanje "sebe van", o čemu će još biti govora) te Sannazzarom (osim općega arkadijskog krajolika, vjerojatno je posrijedi jedan od uzoraka putenog zaljubljenika, satira/pastira, koji izgara od nesretne ljubavi za vilom, usp. $P$ 1331 i d., te bi rado skončao 1424; no isti se motiv pojavljuje u više autora nadahnutih Ovidijem, od Boccacciova Spjeva o fjezolanskim nimfama - prije 1346; o tome u vezi sa Zoranićevim Planinama usp. Grmača 2015: 306 - do Tassova Aminte, napisanog 1573, ali objavljenoga 1580. najprije u Zlatarićevu prijevodu a zatim u izvornoj verziji, dakle nakon Vetranovićeve smrti). Ostavljajući zasad po strani udio talijanskih posredovanja Lukijana i Apuleja u Piligrinu, napominjem da, uz niz klasičnih općih mjesta, Vetranovićev tekst sadrži i preradbu Ezopove odnosno Fedrove basne o gavranu i lisici (usp. P 641-684), na čemu hrvatski pisac po svoj prilici mora zahvaliti talijanskim prevoditeljima i divulgatorima Ezopova opusa u 15. stoljeću Guarinu iz Verone, Ermolau Barbaru Starijemu, Ognibeneu iz Loniga, Lorenzu Valli i Rinucciu iz Castiglionea, kao i običaju humanista, među kojima je i Alberti, da pišu nove basne (usp. Marsh 2003: 9 i passim). No i prije humanističke mode, latinske inačice Ezopove grčke basne, prije svega Fedrova (koju u Satirama spominje i Horacije), a zatim i Apulejeva preradba (usp. Apulej 1991) doživljavaju srednjovjekovne francuske obrade u Marie de France i Romanu o liscu, kao i rane prijevode na talijanski (usp. Bertini 2009).

2 Preciznije obavijesti o Pseudo-Teokritu kao jednome od izvora epizode o vepru, o spjevu L'Adone (1550) Giovannia Tarcagnote kao mogućem posredničkom tekstu između grčkog izvornika i Piligrina te o drugim izravnim i posredovanim odjecima Ovidijevih Pretvorbi u Vetranovićevu spjevu vidi u Lupić 2014: 54-60. 
književnim prilikama tako i navodnoj alegorijskoj svrsi Piligrina "da opjeva jednu kršćansku istinu" - "vjeru kao spasiteljicu” (Medini 1902: 235, 234). Repovi čudnovatoga Medinijeva suda, prema kojemu književni povjesničar pouzdano zna što spjev jest po vrsti, ideologiji i smislu, a što je u njega zalutalo i na njegovo se tijelo neopravdano nakalemilo, u raznim će se inačicama za Piligrinom vući još dugo, kao da stručni čitatelji ne odustaju od nade da će njegove nakazne proturječnosti nekako zataškati ili zanemariti kako bi spjev izveli na pravi put cjelovitosti i jedinstvenosti. ${ }^{3}$

Unatoč dojmu da se Vetranovićev lik-pripovjedač na čudesni put otisnuo "vođen nejasnom pobudom" (Pavličić 2007: 6), kad u tisućama stihova jedva povremeno spominje težnju da dušu oslobodi grijeha i utočište joj nađe u (kršćanskome) Bogu, ${ }^{4}$ nipošto nije "pričudno čudo" $(P$ 666) što i Medini i mnogi kasniji tumači ukupni spjev određuju kao alegoriju putanje isposničkog očišćenja, u najmanju ruku kao logičan ishod simboličke podudarnosti po kojoj se putnik u hodočašće upušta upravo kad pada "pravi rok od višnje ljubavi” ( $P$ 39), ${ }^{5}$ tj. na dan ili u noći uoči Iskupiteljeva rođenja, "kad htješe s nebes doć na zemlju radi nas / sin boga živoga s goruštom ljubavi, / sužanstva vječnoga da svoj puk izbavi” ( $P$ 48-50). Na zaključak da je Piligrin "religiozno alegorijski epos" koji k tome, zajedno s ostalim autorovim djelima, upotpunjuje Vetranovićevu "[i]ntimnu biografiju" (Švelec 1959: 213) osobito utječu citati i lako raspoznatljive aluzije na Božanstvenu komediju, ${ }^{6}$ samo što uskrsno doba Danteova onostranog putovanja

3 Prije je pravilo negoli iznimka primjerice sljedeća Švelecova proturječna tvrdnja da se iz mješovitoga i nerazumljivoga Piligrina ipak dade očitati njegov pravi identitet: "Inspiracija je očito danteovska, što je davno utvrđeno, ali se u djelo slijevaju najrazličitiji elementi, tako da zbog svoje zapletenosti i nepovezanosti ostaje nerazumljivo. Jedno je svakako sigurno: to je pjesma sagrešenja, spoznanja i očišćenja, dakle očito religiozni spjev" (Švelec 1959: 214).

4 "[...] / i drugo ne željeh, razmi sam duši raj, / da moj duh zabude pri višnjoj radosti / sve muke i trude s minutom žalosti” ( $P$ 8-10); "Za-č ve je blizu rok, govoru ja tebi, / sunčani da istok prizivam na nebi, / i ostale svjetlosti i zrake sve ine, / dar božje milosti vrh mene kad sine. [...] a ja ću tamo poć, / gdje me će ozdravit višnjega stvorca moć” (3743-3748).

5 Sintagma se sastoji od semantičkih elemenata dvaju stihova iz molitve kojom se na početku završnoga pjevanja Danteova Raja Sv. Bernard obraća Bogorodici prizivajući njezino providnosno poslanje ("da dieva porodi človjeka i boga", $P$ 46): "termine fisso d'etterno consiglio" (Raj XXXIII 3; u prijevodu Mate Marasa: "utemeljena svrho vječnog čina”); "Nel ventre tuo si raccese l'amore" (Raj XXXIII 7, u Marasovu prijevodu: "Ljubav u tvojoj užga se utrobi”).

6 Najuočljivija je uputa na polazišne stihove i prilike prvoga pjevanja Pakla, koje služi kao uvod u ukupnu Komediju, koju navodim u Kombolovu prijevodu. "Na pola našeg životnoga puta / u mračnoj mi se šumi noga stvori, / jer s ravne staze skrenuvši zaluta” (Pakao I 1-3) i "zalutavši, sa prave staze sađoh" (Pakao I 12) tako u Piligrinu, podalje od početka, postaje "ja 
Vetranović zamjenjuje Božićem, ${ }^{7}$ a tonom tužaljke, kakav se i inače provlači Vetranovićevim sastavcima, najavljuje pripadnost književnim žanrovima isteklima iz pokajničkih psalama; Piligrinove preobrazbe u "zvieren'je razliko" ( $P$ 698), uz biljne i mineralne pretvorbe, prizivaju alegorijsku "topiku degradacije" (Borsetto 2000: 62 odnosno 2002: 248) ljudskoga stanja grijehom što su je crkveni oci naslijedili od antike; ${ }^{8}$ stihovi pak koji opisuju borbu protagonistovih misli aludiraju, kako su primijetili Kravar (1980/ 1981: 319-320) i Fališevac (1989: 218), na Prudencijevu Psihomahiju, prvi pripovjedno-alegorijski prikaz Pavlove crkve što vojuje unutar duše, poprišta borbe Augustinovih dviju suprotstavljenih volja, putene i duhovne. ${ }^{9}$

Pa ipak, većina novijih proučavatelja Piligrina oprezno sumnja u potpunu točnost Medinijeve identifikacije teme, djelomice i zbog povijesnog raskoraka koji Vetranovića dijeli od srednjega vijeka. Uzlaznu metafizičku alegoričnost spjeva, dakako, nije lako otpisati, ali ju nije nužno ni tražiti isključivo u narativizacijama skolastičke teologije. ${ }^{10}$ Naime uvelike sukladnu priču o težnji duše da se, zahvaljujući oduhovljenoj ljubavi prema tjelesnoj ljepoti, spoznajom i krepošću vine do božanskih ideja, kako bi svoju ljudskost izdigla iznad razine koja je čovjeku zajednička sa životinjama te je izdigla do božanske savršenosti, nudi i filozofija firentinske Novoplatonske akade-

bivši srjed puta od moga poroda / [...] zastranih [...]" (P 51 i 56); odjek toga mjesta naći će se i usred Piligrina: "Rasputja ni puta nu nigdjer ne bješe" ( $P$ 3645). Umjesto Danteove šume, alegorije izgubljenosti u grijehu, koja je "divlja" i "gdje drač staze krije" (Pakao I 5), jednaku tjeskobu i strah u Vetranovićeva zalutalog putnika izaziva "vlas od zimnje naravi" $(P 15)$, koja se doduše personificira kao "zima kraljica" $(P$ 22), ali se opisuje veoma sličnim hiperbolama i motivima: "zlosrda i ohola, svoj narav sliedeći, /od mraza vrh kola u draču sjedeći” ( $P$ 23-24); Vetranović preuzima i motiv mraka naprama izostalome suncu.

7 U vezi sa značajkama po kojima se Piligrinovo putovanje razlikuje od Danteova v. Pavličić 2007.

8 Kako napominje Borsetto (usp. 2000: 62-63 odnosno 2002: 248), teza o nadmoćnosti čovjeka kao duhovnog i razumskog bića životinjama u crkvenih otaca (Sv. Ambrozija, Sv. Bernarda, Origena, Sv. Bazilija Velikog i Augustina) nadovezuje se na klasični motiv Kirkine moći da ljude pretvara u niža životinjska bića, o čemu će biti govora nešto dalje.

9 No sukob između tih dviju dimenzija iste duše pisac Ispovijesti (VIII, 9) ipak doživljava kao svojevrsno "pričudno čudo" ("Odakle to neobično čudo? I zašto je tako? Duša zapovijeda tijelu, i odmah joj se tijelo pokorava; duša zapovijeda sebi, i odmah nailazi na otpor", Augustin 1973: 172), štoviše kao nakazan simptom fragmentacije koju se žuri zanijekati u ime jedinstva i cjelovitosti (usp. ibid.: VIII, 10, str. 172-173).

10 "Postoji tendencija da se alegorijski modus tumačenja mita promatra kao isključivo srednjovjekovna pojava, no ona podjednako kao srednjemu vijeku pripada i renesansi” (Carver 2007: 143). 
mije, čije učenje prožima glavninu petrarkističke lirike te uz koju se vezuje i koju svojim Stancama u povodu turnira (1475-1478) alegorizira primjerice i sam Angelo Poliziano. ${ }^{11}$ Noviji tumači Piligrina nastoje načelno smjestiti u kontekst Ficinova i Picova novoplatonizma (usp. Fališevac 2010: 31; Rafolt 2009: 161; Grmača 2013: 267, 286 i dalje), no skloniji su spjev čitati u kršćansko-asketskim okvirima, tj. razumijevajući (anti)junakove djelomične životinjske pretvorbe isključivo kao alegorijske kaznene mjere koje, nalik na Danteov contrapasso, doslovno dočaravaju zvjerske metafore kažnjenikovih grijeha i poroka. Kao i srednjovjekovna, renesansna kultura - ne samo u moralnoj filozofiji i književnosti, nego i na području prirodoslovlja, pogotovo u tzv. fiziognomici - doista sve do kraja 16. stoljeća nastavlja njegovati antičku mitološku i pjesničku tradiciju koja znanstveno-filozofski ugled stječe zahvaljujući Aristotelovoj Prvoj analitici i Povijesti životinja, a prema kojoj se, poglavito u Boetija, Izidora Seviljskog i Alberta Velikog, na tragu hijerarhije bića kakvu ustanovljuje XIV. knjiga Aristotelove Metafizike (usp. Cerbo 2002: 88-89), ${ }^{12}$ tjelesna obilježja pojedinih vrsta živih bića smatraju sukladnima njihovu temperamentu i ćudi, iz čega se izvode (i negativne i pozitivne) analogije između životinja i ljudskih psiholoških odnosno karakternih osobina (usp. Castelli 2002: 50-51). Budući da se prirodnofilozofska i ontološko-metafizička taksonomija već u antici prepleću s mitološkim i književnim motivima, i Platonova i Aristotelova hijerarhijska razdioba bića zarana se vezuju uz zamisao o hibridima i hibridnim pretvorbama, među kojima se dugom i plodnom recepcijom, pa stoga i daljnjim preobrazbama, ističu prije svega zgoda s čarobnicom Kirkom u Homerovoj Odiseji (usp. npr. Yarnall 1994) te Ovidijeve, a zatim i Apulejeve Metamorfoze. Naknadno moralističko tumačenje spomenute epizode Homerove Odiseje (kakvo će egzegeti primjenjivati i na 14. knjigu Ovidijevih Metamorfoza i na cijelu antičku mitologiju) Plotin, Porfirije i Proklo izvode iz učenja što ga Platon iznosi u X. knjizi Države, u Fedru i Timeju, a potanko u Fedonu: duše

11 Poliziana, kao i Sannazzara, Medini u vezi s Vetranovićem ne spominje u tom pogledu, nego nastojeći njihovim primjerom opravdati mitološki pastoralno-bukolički pripovjedni krajolik Piligrina. Pritom nije osobito blagonaklon, jer odgovarajući na pitanje "je li smio Vetranić zaodjeti svoje djelo u tako starinsko ruho, te nam alegoriju o ljudskom životu prenijeti u šume, po kojima satiri i vile kolo vode" (Medini 1902: 234-235), hrvatskome pjesniku ne dopušta što dopušta Talijanima: "Odviše smeta i odviše nas svaki tren odvraća od glavne misli [tj. alegorije vjere kao spasiteljice]" (235).

12 Utjecaj spomenutih patrističkih i skolastičkih izvora Cerbo uočava primjerice u političko-moralnoj metaforici filozofskih pjesama Tommasa Campanelle (usp. Cerbo 2002: 86-87). 
pokojnika koji su za života bili odani tjelesnim užicima nakon smrti ne odlaze u vječnost poput duša čestitih i suzdržanih, nego se vraćaju u zemni svijet gdje poprimaju životinjski oblik koji odgovara njihovu poroku (usp. Tate 1929; Hatzantonis 1960: 261-262; Lamberton 1986; Clarke 1995: 122 i dalje). ${ }^{13}$ Svojevrstan je paradoks što se kasnoantički neoplatonizam isprva suprotstavlja sve moćnijemu kršćanskom nauku u usponu, ali se na koncu s njim poklapa ili čak stapa - primjerice u Augustina - upravo zato što, u nedostatku sluha za ironiju Platonovih osuda pjesništva koje se trudi opravdati i opremiti dostojnom svrhom, na književne predloške od Homera nadalje te pogotovo na pretvorbene priče nadograđuje moralističku alegoriju o lutanju duše što zapada u životinjstvo, stremi da se pročisti i naposljetku uzvisuje do svoje božanske biti, alegoriju istovjetnu religijskome obrascu iskupljenja i spasa (usp. Clarke 1995: 41; 161). Zato uistinu postoji stanovit kontinuitet između srednjovjekovne teologije i humanističkog odnosno renesansnog novoplatonizma, pa renesansni novoplatoničari primjerice dijele s Augustinom i Tomom Akvinskim predodžbu o središnjem položaju čovjeka između životinje i anđela. Međutim barem dva razloga mogu potkrijepiti tvrdnju Dunje Fališevac da se Vetranovićev spjev ne može jednoznačno shvatiti kao prikaz tegobnoga putovanja duše prema savršenstvu alegorijom koja novoplatonističke ideje izmiruje s kršćansko-asketskima (usp. Fališevac 1989: 217).

Prvi se odnosi na korjenitu promjenu što je, s teologijom kombinirajući gnostičke, kabalističke i hermetičke predaje te nadahnut humanističkom posvećenošću istraživanju i preporodnoj obnovi klasične kulture, ${ }^{14}$ Pico della

13 Što se tiče Vetranovićeva spjeva, u Piligrinu "imamo posla s osobitim sinkretizmom kršćanske i antičke tradicije" (Rafolt 2009: 183). U vezi s alegorizacijom antičkih pjesničkih tekstova usp. Grmača 2013: 114 i dalje; o moralnoj alegoričnosti životinjskih preobrazbi u Piligrinu usp. osobito Fališevac 1989: 136; Grmača 2013: 269-278.

14 Pojmu humanizma u vezi s Piligrinom Rafolt pridaje etičko značenje (pa tako zaključuje da je spjev "kritika bestijalnosti suvremenog mu svijeta, [...] afirmacija humanističkih vrijednosti katoličanstva", Rafolt 2009: 188). No treba napomenuti da je povijesni renesansni humanizam - intelektualni pokret ponikao iz proučavanja klasičnih jezika i književnosti (humanae litterae) i potaknut željom da antička kultura bude uzorom za korjenitu obnovu pojma čovjeka, ljudskog društva, institucija i same kršćanske vjere - složena, šarolika i s katoličanstvom nipošto uvijek suglasna kulturna pojava. Humanistički se etos u većine humanista prožima s teologijom (počevši od Petrarke u 14. stoljeću, preko Pica, Erazma, do Giordana Bruna); istodobno, posežući za heterodoksnim učenjima, promičući misao o presudnome značaju samostalne ljudske volje i spoznajne snage uma na području duhovnosti i u odnosu spram Boga, kritičku prosudbu te težnju za moralnom reformom Crkve, humanizam se suprotstavlja njezinu teokratskome dogmatizmu pa izaziva nepovjerenje službene crkvene hijerarhije. 
Mirandola unosi u skolastičko poimanje čovjekova središnjeg mjesta u poretku bića: stvorivši ga umom i voljom obdarena na svoju sliku i priliku, Bog je u čovjeka pohranio sjeme višestrukih mogućnosti da razvije sličnost biljci, životinji ili svojemu tvorcu te mu dao sposobnost da sam izabere između degeneracije u nagonsko zvjerstvo i regeneracije u anđeosko odnosno božansko biće. Iako firentinski filozof ne niječe kršćanske pretpostavke svoje misli, a nakon pravovjernoga obraćenja 1491. čak će svoje tijelo izlagati pokajničkim patnjama, njegov Govor o dostojanstvu čovjekovu čovjeka slavi u njegovoj "svakorodn[osti]" i "svakovrsn[osti]" (Pico 1998: 21 i 23). Upravo se na mješovitosti njegove naravi temelji povlastica zasebna "mikrokozma" (usp. Pico 1994: 25) što ga uživa u svemiru, kao jedino biće koje samo sebe stvara i određuje, ima maštu i samo sebe mijenja (usp. npr. Kristeller 1962: 30; 1998: 66, 106 i passim; Garin 2005: 93). Čovjekova hibridna i protejska sposobnost preobrazbe za Pica dakle nije nužno - barem na vrhuncu najutjecajnije antropocentrične faze njegova djelovanja predmet pokude, nego se, naprotiv, slavi kao čovjekova velebna moć da nadilazi i sam sebe, i ono što nije on sam, jer se njegova bît sastoji u tome što nema biti, nego je, rječnikom aristotelovskog tomizma, ali usuprot njegovim esencijalističkim načelima, potencija za sve moguće aktualizacije: "Tko se takvome našemu kameleonu ne bi divio? Ili, čemu bismo se drugome uopće više divili?" (Pico 1998: 23; usp. Reale i Antiseri 2008b: 168). ${ }^{15}$

Drugi je razlog koji ometa isključivo moralističko-eshatološko čitanje Vetranovićeva spjeva činjenica da tezu o pravocrtnoj usmjerenosti Piligrinove pripovijesti narušavaju neprozirnost navodnih alegorija, nesustavnost

15 Čovjek kakvoga vidi Pico "sebe samoga u lik svekolikog mesa i u duh svekolikog stvorenja da naslika, da iskleše i da preobliči znade", jer "čovjek ne posjeduje nikakvo posebno, njemu prirođeno obličje, već [...] je sav od brojnih pridošlosti i slučajnih nadošlosti" (Pico 1998: 25); Pico ga poziva da ne sliči "životinjama tupim i stoci nerazumnoj” (ibid.), ali ne zato da bi mu nametnuo pokoru i ponizio ga, nego ga - posve suprotno od aristotelističke tomističke etike, u kojoj razum mora postaviti granicu svakoj oholosti i prekomjernom prepuštanju prirodnim pobudama - potaknuo da se smatra jednakim Bogu: "Neka nam sveto neko častohleplje spopadne duh, da bismo, nezadovoljni osrednjostima, napregnuvši sve snage (što možemo, ako hoćemo) prema uzvišenosti pohrlili" (ibid.) dotle da "dostojanstvo i slavu [anđela] sustignemo", jer "ne umijemo ustuknuti i [...] ne možemo podnijeti da u čemu budemo drugi", pa stoga da čak ni anđelima "mi, budemo li samo to htjeli, ni u čemu nećemo biti podređeni" (ibid.: 27). - Dakako, i sam je Pico (čak i zanemarimo li njegovo obraćenje na isposništvo), poput svoje diskurzivne tvorevine, svojevrstan kameleon jer, kako u komentaru napominje priređivač latinsko-talijanskoga izdanja Govora o dostojanstvu čovjekovu (usp. Pico 2014: 14-15) Francesco Bausi, u Raspravama protiv proricateljske astrologije slijedi Plutarha pa s kameleonom uspoređuje laskavca. 
putnikove motivacije, kolebljivost njegova cilja, dojam nasumičnosti epizodnih digresija i izostanak nagovještaja bitnijeg napretka već ionako krivudave potrage koja bi morala tvoriti glavni zaplet, povremene redundancije u iznošenju peripetija, ukratko, niz nesklapnosti i, kako se izrazio Medini, “drugih griješaka" (1902: 235). ${ }^{16}$ "Griješke", reklo bi se, daju pečat i Piligrinovoj i Piligrinovoj sudbini. Naime tijekom cijeloga svojeg pripovjednog putovanja, eponimni protagonist i pripovjedač spjeva zdvaja i cvili nad svojom tužnom i nadasve ružnom sudbinom: nejasni jadi, studen i razdvojenost od vlastitih misli tjeraju ga da krene na prisilno hodočašće ne bi li se skrasio na spokojnu mjestu, ali putem vile i božice na njegovo tijelo nakalemljuju organe raznih životinja i ptica te on zadobiva sve nakaznije oblike pa stoga, sve nagrđeniji i hibridniji, i jače razloge da se tuži na "nevolje s tijelom”, kako je Dolores Grmača u svojoj knjizi o toposu putovanja u starijoj hrvatskoj književnosti duhovito parafrazirala glasoviti naslov Judith Butler, Nevolje s rodom. Neovisno o tome razumijevaju li se Piligrinovi djelomično poživotinjeni udovi kao alegorije antijunakovih moralnih prijestupa, a njegova rugoba kao grešan poremećaj u platonističkoj odnosno patrističkoj hijerarhiji bića, ili pak - za što tekst pruža itekoliko povoda kao hirovi kojima ga nedužnog progoni zlonamjerna "čes", uzastopne tjelesne deformacije koje epskoga hodočasnika pretvaraju u protuprirodno intergeneričko stvorenje upravo dočaravaju uzroke genološko-klasifikacijskih muka - "nevolja sa žanrom ili vrstom", pa onda i s razumijevanjem i tumačenjem - što ih Vetranovićev nedovršeni spjev sve do danas zadaje hrvatskim književnim povjesničarima ${ }^{17}$ Poput Andersenova ružnog pačića Piligrin ne udovoljava mjerilima po kojima bi se uklopio i u jedno labuđe jato, to jest idealan vrstovni skup ili, u ovome slučaju, alegorijsko-pere-

16 Na jedno od mjesta gdje pripovjedač iznova iznosi nešto što je netom već izrekao upozorava Ivan Lupić, objašnjavajući ga mogućnošću prepisivačkog previda, zbog kojega su u prijepisu ostale i odbačena i prepravljena inačica teksta (usp. Lupić 2014: 53, bilj. 39). Tu pretpostavku ne treba odbaciti, premda primjera pripovjednih ponavljanja (po Mediniju, "griješaka") u Piligrinu ima toliko da se ne mogu posve isključiti kao hotimičan integralni dio teksta.

17 Iako je spjev u književnim povijestima stekao "poseban položaj" i "ambivalentan status" (Grmača 2015: 221), Piligrinovim nevoljama s križanjem vrsta još se ne nazire kraj, kako iscrpno pokazuje Dolores Grmača u odjeljku svoje dragocjene rasprave o Piligrinu što ga je posvetila genološko-recepcijskim preobrazbama spjeva (ibid.: 221-239). Rekapitulirajući subgenerička određenja Piligrina kao, redom, "alegorični, autobiografski, religiozni, filozofski, fantastični, peregrinacijski [ep]" (ibid.: 238), autorica zaključuje studiju određujući spjev kao "generički hibridnu alegoriju koja kroz različite transformacije stalno izaziva i destabilizira čitateljeve interpretativne sposobnosti” (ibid.: 295). 
grinacijski podskup epike. Moglo bi se ustvrditi da Piligrinova taksonomijska ekstravagantnost nije "pričudno čudo" ( $P$ 666), kako Vetranovićev pripovjedač naziva i svoje doživljaje i svoju pripovijest, nego gotovo paradigmatski primjer, štoviše, alegorija čudnovatosti ili čak čudovišnosti, ne samo odnosa pojedinačnoga književnog djela prema žanru nego i odnosa povijesnoga književnog sastavka u sklopu nacionalne baštine prema vlastitim, neuhvatljivo mnogostrukim, transhistorijskim i nadnacionalnim uzorima. Žanrovi naime, kaže Adorno u Estetičkoj teoriji, imaju mnogo zajedničkoga s platonskim idejama (usp. Adorno 2002: 201-202), pa utjelovljena književna pojava njihovu transcendentnu savršenost može svojom pojedinačnošću oponašati jedino kao njihova sjena; kad je posrijedi Piligrin naprama bîti epskog pripovijedanja, sjena je uzorno nakaradna. Doda li se tomu krupna uloga što je u putnikovim nevoljama igra pretvorba - tema koja se od klasične starine alegorijski spreže sa značajkama književnog pisma i same alegorije (usp. Clarke 1995), a koja u renesansi doživljava nov zamah - i sam je Piligrin sa svojim pretvorbama alegorija pretvorbe ili alegorija alegorije kao pretvorbene funkcionalnosti književnog teksta, alegorija vječite problematičnosti norme, alegorija prisilne normalizacije otklona usred tako snažna normativnog vrstovnog sustava kakav je preskriptivna klasicistička verzija Aristotelova Pjesničkog umijeća koja, uostalom, poput magarećih ušiju ili svinjskih zuba na čovjeku-Piligrinu, parazitira na Aristotelovu opisu iskustveno zatečena književnog stanja. Kao što je njegov glavni lik parodija čovjeka koji se stidi gubitka izvorno čistog identiteta što ga ionako nije imao, Piligrin je parodija pojma čvrste i čiste generičke određenosti.

Iz često citirane Medinijeve kvalifikacije, prema kojoj je Vetranovićev ep "krparija" i "mozajik, komu kamenčići nijesu složeni harmonički u jednu sliku" (Medini 1902: 235), naslućuje se da je hrvatski pjesnik dobro poznavao raspravu o načelima oponašanja (isprva antičkih, a zatim i talijanskih) autora koja se među "Talijancima", a nadasve humanistima, Petrarkinim tragom vodila u 15. i 16. stoljeću. Štoviše, čini se da Vetranović - slijedeći Leon Battistu Albertia i Erazma (usp. Geri 2011: 42) - zauzima stranu eklektika ili kvintilijanaca, protivnika ciceronijanske, normativno klasicističke struje, ${ }^{18}$

18 Riječ je dakle o humanističkoj polemici koja se u prvome redu odnosi na uzor oponašanja za prozu 15. i 16. stoljeća na latinskome; no kako se od druge polovice 15. stoljeća afirmira tzv. umanesimo volgare, tj. književnost na talijanskome jeziku koja se ugleda na pravila i uzore humanističke produkcije na latinskome, pojmovi koji se odnose na tri škole oponašanja (kvintilijanizam-eklektizam; ciceronijanizam ili strogo pridržavanje jedinstvenog uzora; apulejanizam ili arhaizam) protežu se na razlike u poetikama; usp. D’Amico 1984; Carver 2007: 262 i d. 
zastupnice kanonizacije jedinstvenih latinskih i talijanskih uzora za prozu odnosno stihove, koju Bembo ustoličuje kao mjerodavnu u prvoj trećini šesnaestoga stoljeća. Nasuprot težnji klasicistički nastrojenih humanista da se stilski ujednačuju prema posvećenom obrascu, Leon Battista Alberti u nekoliko navrata navodi Terencijevu krilaticu "Ne može se reći ništa što već nije bilo rečeno", ${ }_{19}$ izrijekom uspoređujući rad humanističkog pisca ali i sveobuhvatnu retoriku citatnosti kojom su se ravnali i autori što ih kao uzore pojedinih Vetranovićevih epizoda imenuje Medini - s oblikovanjem podnog mozaika od drevnih mramornih pločica arhitektonskih starina te pritom ističući da vrijednost novoga djela proizvodi varietas rekombinacije elemenata u skladu s posebnostima vlastitog nauma (usp. Cardini 1990: 4-5, 25; Di Stefano 2000: 77). Albertieva mozaičnost podrazumijeva skladnu cjelinu dijelova, kakvu, drži Medini, Piligrin ne dostiže. No je li moguće da i Piligrinovim "mozajikom" ravna neko načelo koje čitatelju promiče ako unaprijed odluči o žanru, modusu, podrijetlu kamenčića i značenju spjeva, te da je Piligrin čitljiviji na podlozi drukčije, satirične, ozbiljno-komične tradicije književnih metamorfoza koju je i sam Alberti pomogao oživjeti među europskim piscima i filozofima?20

Makar koliko naum pripovijesti o Piligrinovim doživljajima pokušavali pojmiti kao anamnestički povratak duše iz poružnjenoga tijela u ljepotu obličja koju joj je prvotno namijenilo njezino božansko podrijetlo, i dalje mu ne uspijevamo privesti logiku Vetranovićevih tekstualnih intarzija: pošto pobožni uvod iskaže zahvalnost utjelovljenome Iskupitelju, Vetranovićev hodočasnik prijeđe prag sna i nađe se u poganskom svijetu sebičnih, taštih, bahatih i osvetoljubivih bogova - zapravo, većinom božica - i njihovih družbenika i družbenica, u kojemu zazivi Previšnjemu nisu više od puke

19 U tekstovima Theogenius i Profugiorum ab erumna libri, usp. Ceron 2015: 14.

20 Osim Prohaskine teze iz 1919. prema kojoj je Vetranovićev spjev "satira na pogansku renesansu”, Dolores Grmača ističe da je Marijan Stojković 1916. Piligrina povezao s antičkim romanom i s Folengovim žanrovski, stilski i jezično eksperimentalnim djelom Caos del Triperuno (1526-1527), te i sama razmatra moguće odnose Piligrina s Folengovim makaronskim komično-viteškim spjevom Baldus (Grmača 2015: 229, 238; 265-266), osobito u pogledu “opisa naopakoga, otuđenoga, stranoga svijeta kojim lutaju raznoliki likovi, [...] opisa fantastičnog putovanja i pojedinih motiva, komičnih i parodijskih tonova, protucrkvene satire, inkorporiranja grotesknih elemenata, deformiranih tijela, nasilja, hibridnih bića, mitoloških likova, miješanja različitih tematskih svjetova, odnosa doslovnih i alegorijskih značenja, kao i naglog završetka djela, odnosno prekidanja narativne niti” (ibid.: 265). Usporedba je veoma umjesna: Folengo se, upravo kao i Rabelais, na kojega će utjecati zajedno s Pulciem, također uklapa među renesansne lukijaniste, o čemu će biti riječi nešto dalje. 
formule. Osim slučajne krađe Dijanina pehara i laži kojom je pokuša prikriti, Piligrinu bi se teško mogao pripisati neki izričit grijeh ili prijestup - pa čak ga i za erotsku znatiželju, nalik na Akteonovu ili Psihinu, nimfe i božice optužuju posve bezrazložno - osim neprestane, posve ljudske i nimalo zvjerske žeđi koju mu uglavnom zabranjuju utažiti ili je, kad se napije, kažnjavaju unakazujući ga životinjskim izraslinama. Piligrin nije kriv ni za osjetilnu pohotu, nego se, poput Odiseja na Kirkinu posjedu, odupire pozivima animaliziranih ljubavnika da im se pridruži ( $P$ 3700; 3750-57). U epizodama koje bi mogle posredno zrcaliti mogući putnikov grijeh i primjerenu kaznu, opisi nasilja, premlaćivanja, mučenja, uboda kukaca, patnje i poniženja sadistički su, posve nesrazmjerni žrtvinoj krivnji i prepušteni hirovima, a ne pravednu providnosnom poretku ili nepristranoj Božjoj srdžbi. Satiru koji želi ukrotiti neposlušnog magarca jednu od takvih kaznenih terapija "liek" (P 3389) od kojega ce "oholi tovar taj" (P 3358) "ozdravit" ( $P$ 3365) - savjetuje jedini životinjski lik (usp. $P$ 3357-3390) kojemu bi se, na temelju odnosa što ih uspostavlja intarzija danteovskih citatnih elemenata, mogla utvrditi privremena i uvjetna alegorijska funkcija ekvivalentna Danteovu Vergiliju, alegoriji razuma i filozofije: ${ }^{21}$ "drum pravi” $(P$ 218, 2884, 2985, $3520)$ s kojega je "stranputno" ( $P$ 2287) zalutao Piligrinu će pokazati majmunica ("Mojemuča", usp. $P$ 205, passim) pošto mu vrati odbjegle misli zauzvrat za cipele. Dakako, nije jasno kako bi se, po majmuničinoj uputi, Piligrin mogao vratiti na ravni put te se dakle domoći spasa, ako taj put vodi u špilju čarobnice Kirke stručnije za pretvorbu ljudi u zvijeri negoli obratno. ${ }^{22}$ Samo Medini zna zašto je mojemuču očitao kao simbol vjere

21 D. Grmača iznosi argument hirovitosti u prilog pretpostavci da je "majmunica [...] personifikacija sudbine" (tj. “česti” odnosno fortune, Grmača 2015: 261; usp. 262-266); među proturječjima i hibridima spjeva ni tu mogućnost ne treba isključiti, iako nije osobito izgledno da bi se ravnodušna Fortuna trsila objašnjavati Augustinovo umovanje o sukobu među čovjekovim mislima ( $P$ 3001-3022) što ga autorica navodi (Grmača 2015: 262).

22 No Kirkina moć je ipak dvosmjerna, u skladu s već spominjanom tradicijom platonizacijskog tumačenja Homerovih spjevova te napose Porfirijeve alegorizacije Kirke (usp. Lamberton 1986: 42; 115-119 i d.; o stereotipnim i subverzivnim preobrazbama Kirke u renesansi usp. osobito Yarnall 1994: 99-126) kojom se čarobnici pripisuje moć da niske ljude pretvara u svinje ali i da filozofe uvodi u viši svijet (Lamberton 1986: 153). Kad pokuca na vrata špilje, Piligrinu će se ukazati jedno od grotesknijih bića u spjevu (usp. Fališevac 1989), Kirkina dvorkinja, naborana starica slična Meduzi (na glavi su joj "pipci”, $P$ 4207; "nemila i gruba" $P$ 4197, sa "samo dva zuba", 4198, toliko "grda stvar i velmi nemila", 4209, da se putniku "mnjaše, paklena da je neman", 4201) i ružnoj alegorijskoj ženskoj spodobi iz XIX. pjevanja Čistilišta ("meni se u snu mucava ukáza / razroka žena, nogu iskrivljenih, / sakatih ruku i 
(1902: 232), ali se i atributi razbora - ako majmunicu smjestimo u asocijacijski sklop Danteove Komedije - doimaju prilično nakaradno. Taj stvor naime nema nimalo dostojanstvenu ulogu u humanističkim kontekstima: eklektik Poliziano, raspravljajući o načelu oponašanja s ciceronijancem Paolom Cortesiem, s "majmunom" (odnosno majmunicom) i papagajem uspoređuje ropski pasivne i nesamosvojne nasljedovatelje Cicerona. ${ }^{23}$ Spoj pak majmunice i želje za cipelama podsjeća na neslanu šalu Pulcieva diva Morgantea, Pantagruelova uzora, koji je svojemu prijatelju Margutteu skrio čizme dok je ovaj spavao, a kad se dotični probudio, ugledavši majmuna kako navlači njegove čizme, stane se nezaustavljivo smijati te na koncu umre od smijeha. Čini se dakle da je kršćansko-platonističko lice Vetranovićeva spjeva samo dio - pa makar i glava - na trupu posve druge književne i filozofske vrste, ${ }^{24}$ kentaurski mozaik “skrpljen”, kako je posve ispravno

blijedih obraza", 7-9), koja se zatim, i dalje u snu onostranog hodočasnika Dantea, pretvori u primamljivu sirenu kakva je s puta skrenula Odiseja, a koju je pjesnik već evocirao u XII. pjevanju Pakla, vjerojatno - budući da je Homerove pripovijesti poznavao uglavnom preko posrednika, od Vergilija, Ovidija, Cicerona, Boetija - negativnom simbolizmom pohlepe odnosno požude spajajući sirene, Kirku i Kalipso (Lamberton 1986: 295; usp. i članak Sirene (1970) Giorgia Padoana u Enciclopedia Dantesca, http://www.treccani.it/enciclopedia/ sirene_\%28Enciclopedia-Dantesca\%29/). Značajan predložak Vetranovićevoj starici potječe iz izvora mnoštva drugih pojedinosti u spjevu, kako ćemo vidjeti, Apulejeva Zlatnog magarca, gdje razbojničku družinu poslužuje "baba, pogurena od godina", koju razbojnici neštedimice obasipaju uvredama: "Hej, stara mrcino, odvratna babetino i ruglo živih, jedini stvore koji bi se i paklu gadio", Apulej 1997: 63). Međutim, Vetranovićev kudikamo iscrpniji opis staričine ružnoće (od $P 4195$ sve do 4228) koji se, u očitoj retoričkoj šali, predstavlja ne samo kao nemoguć za pripovjedača, nego za ikojega pjesnika ("A ostalu nie mi kad grdobu skladati, / vrjemena kratka rad ni u pjesan zbrajati; / za-č toli grdu stvar ne bi ju po vas viek / penilom nikadar upengao živ človjek", $P$ 4215-4218), ima glasovit renesansni uzor, Berniev burleskni sonet Chiome d' argento fino, irte e attorte (1530) koji parodira Bembovu inačicu Petrarkinih pohvala Laurinoj ljepoti i plavoj kosi. O motivu nakazne žene u Držićevoj Noveli od Stanca usp. Šundalić 2009: 178.

23 Angelo Poliziano al suo Paolo Cortese u Garin 1952: 903.

24 Kako podsjeća Carver (usp. 2007: 2), na početku Pjesničkoga umijeća, zabranu miješanja tragičnog i komičnog modusa te zahtjev za skladnom uravnoteženošću književnog djela Horacije ilustrira metaforom tjelesne hibridnosti - spoja konjske glave i ljudskog trupa koji bi svakoga nagnao na smijeh; nasadivši na ljudsko tijelo ne konjsku, nego magareću glavu, a uz to i uzvišeni zanos Izidinim misterijskim kultom na sablažnjivu zbirku nalik na Aristidove erotske Miletske priče, dodaje Carver (usp. ibid.), Apulej kao da je odgovorio na Horacijev izazov. Ne treba međutim zaboraviti da bez pokusne hibridnosti nema remek-djela ni izvan ludične ili ozbiljno-komične književnosti: upravo je inovativna mješavina komičnog i tragičnog stila jedan od razloga što Dante svoj spjev naziva "komedijom", pa satiričnoga Horacija, unatoč 
primijetio Medini (usp. 1902: 231), od pločica pokupljenih iz (bar naoko) nesumjerljivih izvora i izvornika, analogno nakaradno mješovitoj spodobi njegova protagonista-pripovjedača, što ga isprekidani razvoj pripovijesti vodi k navodnome cilju duhovnosti i ljepote, ali je uvijek na rubu da se prometne u satiru ideologije koja taj cilj projicira i parodiji njezinih književnih spomenika. Kako sam već naznačila, svi uzori koji su Piligrinu, s poetičkim načelom mozaična slaganja metamorfički preuređenih okrajaka zgoda i slika, namrli zalihu motiva - putovanja u onostranost bilo fizičkim putovanjem, bilo u snu; razgovora s dušama pokojnika, silaska u svijet mrtvih po proroštva, izdvojenosti iz vlastita vremena i mjesta da bi se izdaleka promotrio zemaljski život, boravka među bogovima dok vijećaju i sude, pretvorbenih pripovijesti i njihovih vlastitih nebrojenih pretvorba, figure alegorije alegorijski utjelovljene u motivu pretvorbe - oduvijek su bili, i sve do danas jesu, štivo koje podliježe dvostrukom čitanju, od kojih je jedno duhovno, pobožno, ozbiljno, vjersko ili misterijsko, a drugo drsko i izazovno, subverzivno i prijestupničko, ironično i ludično, parodično i satirično, sklono hibridima i intergeneričnosti, bezobzirno prema svetinjama, bile one čistoća žanra ili modusa, božanstvo, moralni nalog, etička zabrana ili sama granica neozbiljnosti: smrt. Takvoj dvojnosti tumačenja ne umiče ni hibridni Piligrin, podjednako (ne)čitljiv i kao priča o kušnjama na putu do posvećenja u mistična otajstva i kao aluzivna igra satiričkih obrata i parodijskih kontaminacija.

Pretpostavku o dvostrukoj kodiranosti koju Vetranovićev spjev baštini od svojih šarolikih književnih predaka i suvremenika potkrepljuju podatci o golemoj raširenosti rukopisa, a zatim i tiskanih izdanja, prijevoda, komentara i oponašateljskih preradaba te pogotovo o dvojakoj - platonizacijskoj i satiričkoj - recepciji, što ih u humanističkoj i renesansnoj književnosti doživljavaju tekstovi dvaju i Vetranoviću nezaobilaznih autora iz drugoga stoljeća nove ere, promicatelja žanrovskih križanaca između komične književnosti i filozofije: Apuleja iz Madaure (poznatoga već u srednjemu vijeku, kad se među nasljedovatelje njegovih Metamorfoza ubraja i Piligrinov daleki predak Roman o ruži , da bi zatim postao nadahnućem humanista od Boccaccia nadalje) i novootkrivenoga Lukijana iz Samozate, čija je menipska

njemu samome, u IV. pjevanju Pakla uvrštava među najveće klasične pjesnike - uz Homera, Vergilija, Ovidija, Lukana - te im zatim pridružuje i samoga sebe. 
satira na raznolike načine djelovala u ranoj novovjekovnoj književnosti (usp. npr. Bahtin 1967, 1984a i 1984b; Marsh 1998; Geri 2011), od Poggia Bracciolinia, Albertia i Giovannia Pontana, Rabelaisa, Erazma i Thomasa Morea, ${ }^{25}$ preko Swifta, Voltairea, Diderota, Sternea i Leopardia, do Dostojevskoga, Nietzschea i Joycea. ${ }^{26}$

Upravo pokretački motiv Piligrina - junakov privremeni premještaj u neki drugi svijet, citatima i aluzijama uočljivo prispodobljen Danteovu zagrobnome putovanju - čitatelja navodi da spjevu pripiše ozbiljnu zaokupljenost moralnim i metafizičkim pitanjima. No prema našoj alternativnoj pretpostavci, Danteova nekyia ili katabaza (koju sam autor Komedije u II. pjevanju Pakla izrijekom svrstava uz bok Enejinu posjetu podzemnom svijetu u VI. pjevanju Eneide i Pavlovu boravku na nebu o kojemu apostol pripovijeda u Drugoj poslanici Korinćanima) ${ }^{27}$ prema čudnovatoj Piligrinovoj citatnoj izvedbi odnosi se - kao što je slučaj, kako ćemo vidjeti, s više nego jednim njegovim talijanskim intertekstom - jednako kao što se posjeti podzemlju u XI. i XXIV. pjevanju Homerove Odiseje odnose prema Lukijanovim ozbiljno-komičnim verzijama Menipovih boravaka u svijetu mrtvih ili na mjesecu. Slično se može reći i za moralistički alegoriziranu epizodu Homerova spjeva u kojemu čarobnica Kirka Odisejeve ljude promeće u svinje (metamorfičku pripovijest koja u platonista s vremenom nadomješta iscrpljeni topos silaska u svijet mrtvih, usp. Lamberton 1986: 119), koju Lukijan parodijski kontaminira Pitagorinim učenjem o metempsihozi

25 O Lukijanu i posljednjoj trojici lukijanista u vezi s Držićem usp. Košuta 2008: 267, n. 22; 269; 278, 298, 299.

26 Što se tiče talijanskih lukijanista od 15. stoljeća nadalje, mogli bismo dodati i nekoliko autora koji se u ovome tekstu ili u citiranim radovima spominju u vezi s Piligrinom, kao što su Pulci, Folengo, Berni, kasniji Tassoni itd.

27 Da je Dante dobro poznavao i veoma raširenu apokrifnu Visio Pauli pokazuju (uz XIII. poslanicu Cangrandeu della Scali, na koju upućuje Sapegnov komentar) struktura Danteova zagrobnog svijeta i nekoliko mjesta u spjevu (npr. Pakao III 34-36 i 37-39; prema Continiu i Giacaloneu, također i Raj XXVIII 4-9; u vezi s Paklom II 85-93 Hollander se poziva na Grandgenta, u vezi s Paklom XI 5 na Mazzonija odnosno Silversteina, a u vezi s Paklom XII 103 na mišljenje Romana Penne; u vezi s Paklom XII 116 Sapegno navodi Gmelina). Većina novijih komentatora Komedije (npr. Pietrobono, Mattalia, D’Ovidio, Torraca, Fallani, Bosco i Reggio, Chiavacci Leonardi) smatra da se Pakao II 28-33 referira isključivo na 2Kor 12,2-4, tj. na Pavlov boravak na nebu, a ne na spomenutu Pavlovu Apokalipsu, prema kojoj je Pavao sišao i u pakao. Naime spomen Eneje i Pavla kao Danteovih prethodnika ima važnu metatekstualnu funkciju jer kao pjesničko-proročanske uzore Komedije uspostavlja Eneidu i Bibliju. Svi navedeni podaci dostupni su na https://dante.dartmouth.edu/; o Pavlovome viđenju te o njegovu mogućem dodiru s Paklom II usp. Grmača 2015: 89-91. 
primjerice u dijalogu San ili Pijetao (usp. Lukijan 2002: 377-400) i varira u kratkome apokrifnom romanu Magarac, što se od 1494. u latinskome prijevodu objavljivao pod Lukijanovim imenom (usp. Catanorchi 2003: 40). ${ }^{28}$ Podsjetimo da na put grotesknih pretvorba po alternativnom svijetu Piligrina odvode "san" i "njeka boljezan". ${ }^{29}$ Prvi mu je sugovornik bivši čovjek Javor - pokojnik pretvoren u biljku - koji Piligrinu pripovijeda svoje nevolje nalik na sudbinu Lukijanova Timona (prema kojemu će u 15. stoljeću Boiardo napisati dramski tekst prije Shakespearea), pa je dakle posrijedi spoj nekyije i metamorfoze. ${ }^{30}$ Budući da je, kako smo rekli, Piligrin dvostruko kodiran, san bi podjednako mogao biti i proročanski uvid u pravu istinu, i prijelaz u predjele metamorfoza književnih metamorfoza. "Boljezan" bi pak mogla s jedne strane biti Augustinova i Petrarkina "opasna i ukorijenjena bolest" (Petrarca 1987: 19) volje, "zlokobna bolest duše koju su moderni pisci nazvali accidia, a antički aegritudo" (ibid.: 93), "što čovjeku, koji je "najubogija od svih životinja" (ibid.: 80), priječi da se odupre materijalnome

28 Danas se kao autor grčkoga Magarca navodi Pseudo-Lukijan; zabunu je izazvalo protagonistovo ime Lucije, "poteklo iz izgubljenih grčkih Metamorfoza 'Lucija iz Patre', od kojih su zaplete preuzeli i Apulejeve Metamorfoze i Pseudo-Lukijanov Onos" (Gaisser Haig 2008: 18; usp. Harrison 2000: 218; Acocella 2001; Carver 2007: 54 i passim). No motiv magarca skopčan s porugom prema filozofskim autoritetima primjerice Aristotelovoj filozofiji prirode, embriologiji i "logičkom nauku o specifičnim svojstvima" (Gregorićev komentar u Lukijan 2002a: 81, bilj. 66), pojavljuje se u autentičnome Lukijanovu dijalogu Svjetonazori na dražbi, gdje Aristotelovoj esencijalističkoj hijerarhiji bića antifrastički suprotstavlja hibridnost i intergeneričnost: “A tek da čuješ druge mnogo oštroumnije stvari: o sjemenu, rađanju i oblikovanju embrija u maternici, pa o tome da čovjek jest, a magarac nije sposoban za smijeh, a niti za gradnju, niti za plovidbu..." (Lukijan 2002a: 59).

29 "Prigna me, vajmeh, san u moj trud najveći / i njeka boljezan, ku ne viem izreći, / pod njeki javor suh, visoko vrh gore, / da se moj trudan duh pokriepit ne more" ( $P$ 85-88).

30 "Simbolička i ikonografska tradicija ne poznaje motiv javora koji govori" (Rafolt 2009: 185), ali književnost itekako poznaje slučaj metamorfoze čovjeka u stablo ili bar biljku koja govori: najslavniji primjer je XIII. pjevanje Danteova Pakla, gdje samoubojica Pier della Vigna, sicilijanski pjesnik iz prve polovice 13. stoljeća i savjetnik cara Fridrika II, Danteu iznosi svoju bolnu sudbinu; k tome Vergilijev lik izrijekom priziva III. pjevanje svoje Eneide prema kojemu Danteova mašta oblikuje zagrobnu preobrazbu jer ondje - upravo kao što Dante na Vergilijev poticaj otkine "grančicu jednu na veliku trnu" (Pakao XIII 32), na što biljka prokrvari i progovori - Eneja iščupa granu iz drenova grma, raskrvari ga i dozna da je grm ubijeni trojanski kraljević Polidor. Spomenutim Danteovim mjestom poigrava se VI. pjevanje Ariostova Mahnitog Orlan$d a$ (oktave 27-56), gdje se stablo mirte predstavlja kao vitez Astolfo, kojega je u biljku pretvorila čarobnica Alcina, Kirkina dvojnica. I u Apulejevu Zlatnome magarcu među mnogim neživim stvarima proročki govori trstika (usp. Apulej 1997: 105).

31 O tome u vezi s Piligrinom v. poglavlje "Melankolija Piligrina" u Šimić 2017, a u vezi s Držićem usp. Grmača 2010: 253. 
i grešnome, pa se on može jedino "uz Božje vodstvo [...] spasiti od tolikih krivudavih staza" i pomoći "da se burna fortuna ne pomami" (ibid.: 189), ali bi s druge strane mogla odgovarati i neumitnome prirodnom stanju duševne nepostojanosti i izloženosti udarcima fortune, koje je, smatra Alberti, uzalud liječiti bilo stoičkom strpljivošću bilo Petrarkinom vjerom u Providnost (usp. Quondam 2010: 380-381; Ceron 2015), te tu čovjeku imanentnu boljku olakšati može jedino štivo kakvo su lukijanski odmaknuti šaljivi sastavci Intercoenales koji, kao prethodnica "vedre znanosti”, izazivaju kinički "smijeh i veselost" (Alberti 1998: 21). ${ }^{32}$ Ako prihvatimo ovu posljednju mogućnost - da tragom Lukijana i Albertia Piligrinova kuknjava nad nesrećom svoje "česti” i nemilosrdnošću Fortune personificirane bešćutnim božicama i bogovima što se nastrano razonode progoneći ga i nagrđujući (premda o toj istoj ćudljivoj Fortuni ovise i sami, usp. npr. Alberti 1998: 29) $)^{33}$ na ljudske životne i političke nedaće zapravo odgovara smijehom - nezgrapnosti disparatnih motivskih sklopova, generička mozaičnost i neprozirnosti tobožnjih alegorija poprimaju drukčiju vrstu dosljednosti, a Piligrinova umna šupljina, nemoć "sviesti” i nakazne preobrazbe počinju dočaravati redoviti čovjekov položaj. Stoga su njegovo trajno stanje "san" (a kako tvrdi Ciceronova rasprava $O$ proricanju, "umovi ljudi su, dok spavaju, potpuno slobodni i odvojeni od tijela", Alberti 1998: 29) i "njeka boljezan", svojevrsno ludilo, zbog kojega je, kao svaki čovjek, Piligrin stalno "sebe van".

Kad je među Piligrinove talijanske uzore ubrojio Ariosta, Medini je vjerojatno imao na umu odjek mahnitosti viteza Orlanda čiji razum, zajedno sa svim drugim stvarima koje su se izgubile na zemlji, dospijeva na Mjesec,

32 Osim dijaloga o strpljivosti i o potištenosti u lukijanističkoj zbirci Intercoenales (usp. talijanski prijevod u Alberti 1998: 34-38 i 94-104), problemom mogućnosti duševnoga sklada i iscjeljivanja strašću uzrokovane neuravnoteženosti Alberti se bavi i u dijalozima Theogenius i Profugiorum ab erumna libri III, nadahnutima Senekinim dijalogom De tranquillitate animi i Petrarkinim De remediis utriusque fortunae (usp. Panizza 1991; Ceron 2015); ovo posljednje djelo pak razrađuje Ciceronovu tezu o filozofiji kao lijeku za um i dušu (usp. Panizza 1991).

33 Odbojne i zloćudne značajke bogova predmet su Albertieva latinskoga menipskog romana naslovljenoga po grčkome bogu poruge, satire i pjesnika Momus; u mozaiku Albertievih antičkih predložaka odskaču Lukijanovi dijalozi Zeus u tragičkoj ulozi i Skupština bogova. I Albertiev se Mom(us) drskim smijehom odupire bahatosti moćnijih bogova te biva izgnan s Olimpa, no na meti satire ujedno je ludilo čovjekove umišljenosti, ambicije i pohlepe (usp. Geri 2011: 71-117 te Boschetto 1995; Di Grado 1997; Bonazzi 2008). Roman je jedan od mogućih posredničkih uzora prikaza okrutnosti svojeglavih božica i bogova te njihova vijećanja u Piligrinu. 
gdje ga pod vodstvom Sv. Ivana pronalazi i odakle ga vraća - jednako kao i svoj vlastiti razum - vitez Astolfo. Ariostova epizoda (XXXIV 70-92 i XXV 1-30, v. Ariosto 1997: 1072-1076; 1085-1091) - koja ujedno parodira Danteovu Komediju, parafrazirajući i citirajući iz nje sintagme i cijele stihove, ali izokrećući ishod puta njegova hodočasnika prema vrhovnoj spoznaji i kontemplaciji savršenoga poretka svijeta zaslugom Božje milosti u komično kaotičan prizor gdje se Astolfo suočava s posvemašnjom nasumičnošću i ispraznošću znanja, ruševinama svakoga truda, krhkošću ljudske pameti i izostankom višnjeg smisla (usp. Zatti 1989: 373) - preuzima pak Albertievu razradu u tekstu San iz zbirke Intercoenales (usp. Alberti 1998: 76-80), Lukijanova motiva puta na mjesec i pogleda na zemaljski svijet iz svemirskog očišta u Istinitim pripovijestima i Ikaromenipu (usp. npr. Segre 1966: 85-95; Santoro 1989: 237-262; Zatti 1989; Marsh 1998: 92-100; Catanorchi 2003).

Piligrinove odbjegle misli, nakon niza metamorfoza u jestive, ali teško probavljive predmete, praznoglavome vlasniku (na kojega se zato barem djelomično odnosi Javorova dijagnoza: "za-č se sad radjaju / mahniti i ludi", P 241-242) tobože mudrim savjetima vraća majmunica, prema našoj pretpostavci glasnogovornica razuma i filozofije - oksimoronska tvorba dostojna spektra impossibilia iz Lukijanovih Istinitih pripovijesti, priča čiju istinitost jamči lažljivi pripovjedač (usp. Lukijan 2002: 254). Majmunica kao zastupnica razboritosti dostojna je baštinica svoje filozofske prethodnice, jer i Pohvalu ludosti Lukijanova štovatelja Erazma autoritativno izgovara glavom Ludost, a to, kad tvrdi kako je ludost jedino čega ima premalo na mjesečevu odlagalištu izgubljenih stvari, tj. da je na zemlji uvijek ima u izobilju, svakako na umu ima i pripovjedač Mahnitoga Orlanda (XXXIV 81, usp. Ariosto 1997: 1074; usp. istovjetnu tvrdnju u Snu, Alberti 1998: 78). Mjesečev prizor bočica s natpisima vlasnika izgubljenih razbora u Ariostovu spjevu (XXXIV 82-84, usp. Ariosto 1997: 1075; usp. i Alberti 1998: 78), odakle u Vetranovićev dospijevaju misli bjegunice, također je samo jedna od njihovih postaja jer su u Mahnitog Orlanda doletjele iz Albertieva lukijanističkog dijaloga Somnium u kojemu menipski lik, bibliofil i kolekcionar knjiga Libripeta, u zemlji snova - kao uostalom i Piligrin pošto je vidio onostranost čudovišno izobličenih ljudskih lica, nalazi pozamašan režanj vlastitoga mozga, samo što mu se ne dopušta da njime ispuni "desnu stranu glave, koja je prazna i beskorisna" (Alberti 1998: 78). Ispražnjena glava - no u Snu Lepid opominje Libripetu da svoj mozak ne smatra praznim kad je pun ludosti (usp. ibid.) - nije dakle slučajan fantastični motiv, 
nego metafora polemične Albertieve antropologije s kojom će Machiavellieva imati mnogo zajedničkoga: nasuprot divljenju čovjekovoj svemoći i središnjemu mjestu u svemiru, kakvo nalazimo u Giannozza Manettia prije, a u Pica della Mirandole nakon Albertia premda poput njih uvjeren u jedinstvenu ljudsku spoznajnu i stvaralačku snagu, Alberti čovjeka ne poima kao biće u kojemu stoluje duša koja pamti svoje božansko podrijetlo, pa mu se duhovnim rastom može nanovo približiti, nego ćudljiva i nestalna priroda, unutarnji uzrok osjećaja potištenosti i tjeskobe, kojemu se pridružuju vanjski, slijepi slučaj, Fortuna, sudbina ili, kako Piligrin višekratno podsjeća, "čês". Promotrimo li s Albertieva stajališta Vetranovićeva hodočasnika, zdvojnog nad unutarnjom manjkavošću razuma kao duševnog uporišta, shrvanog izvanjskim nedaćama i poput karikature Picova čovjeka-kameleona podložnog svakojakim (osobito nakaznim) pretvorbama, postaje razumljivo zašto se "svies", koju je Piligrin poslao da traži zemaljsko mjesto gdje bi našao duševni spokoj, vraća neobavljena posla: čovjekov život je patnja, tegoba i bezizgledna borba, izvana sa sudbinom, a iznutra sa samim sobom i vlastitom nepostojanošću. Nema načina da se krepošću izbjegnu udarci “česti” (tj. silnika), kao ni da se stekne neki drugi, bolji svijet; osim ako to nije svijet u kojemu čovjek može samoga sebe nadići smijući se vlastitome neznanju, nakaradnosti i slabosti - svijet književnosti ili filozofije, što je gotovo isto, kako Albertiev Lepid kaže povratniku iz zemlje snova: "Ti si zapravo više filozofije naučio na samome tom putovanju, nego za svih godina što si ih proveo u svojoj golemoj knjižnici koju držiš stalno zaključanu" (Alberti 1998: 79).

Lukijanov prodor među europske humaniste utire put i posve drukčijim čitanjima Apulejevih Metamorfoza koje dotad - no među mnogim renesansnim autorima i dalje - slove i oponašaju se isključivo kao moralno-platonistička alegorija (usp. npr. Harrison 2000: 252; Carver 2007; Gollnick 1999; Gaisser Haig 2008). Među raznolikim Vetranoviću možda poznatim talijanskim preradbama u Boccaccia (romanom Filocolo, novelama Dekamerona u stilu grčkih romana, usp. Candido 2016) filtriranih Apulejevih Metamorfoza treba spomenuti roman Hypnerotomachia Poliphili (1499) Francesca Colonne ${ }^{34}$ i, na njegovu tragu, u tadašnjoj Europi veoma popularni

34 Pripisivan raznim autorima, a među njima i Albertiu, s kojim se povezivalo mnoštvo umetnutih učenih rasprava o likovnim umjetnostima i ekfrastičnih opisa i komentara slika, kipova, vrtova i arhitekture, eklektični, intermedijalni, jezično kompozitni, enciklopedijski Polifilov boj sna i ljubavi Apulejeve Metamorfoze nasljeduje u humanističkom duhu strasti prema starinama, 
fantastično-ljubavni roman Jacopa Cavicea, zanimljiva naslova Il Peregrino (1508): ${ }^{35}$ po međusobnoj razlici, ta dva srodna djela - Hypnerotomachia je ezoterična neoplatonička alegorija, a Peregrino odiše lukijanskom komikom i završava putenim sjedinjenjem ljubavnika (usp. Roush 2015: 129-130) zoran su primjer dviju suprotnih tradicija tumačenja i oponašanja Apulejevih Metamorfoza, po čemu kao da obnavljaju raskorak između dvaju Romana o ruži (ozbiljno-platoničkog teksta Guillaumea de Lorrisa odnosno lascivno-humorističnog nastavka Jeana de Meuna), također nasljednika Metamorfo$z a$. Dvojaka europska recepcija Zlatnoga magarca ovdje će nam, naravno, poslužiti kao potkrepa tezi o "dvostrukoj kodiranosti” Piligrina; no budući da u kritičkoj povijesti čitanja Vetranovićeva spjeva prevladava pozornost prema metafizičkim implikacijama teksta, ostaje pitanje koliki su izgledi da je Piligrin mogao pod hodočasničkim ruhom prokrijumčariti i suprotnu komično-satiričnu, subverzivnu inačicu svojega nadahnuća.

Kako svojom raspravom o komičnoj travestiji Zlatnoga magarca, te osobito umetnute priče o Kupidu i Psihi, u Držićevu Grižuli potanko pokazala Čale Feldman (2016), književni i kazališni Dubrovnik u 16. stoljeću, uklju-

ljepoti i znanju; feritas glavnoga lika, za razliku od Lucijeve, samo je metafora njegove erotskospoznajne požude, no u tekstu se izrijekom, u svrhu moralne pouke, Polifilovo stanje uspoređuje s Lucijevom pretvorbom u magarca (usp. Colonna 2010: 80-81, 105). Nakon obroka ruža i lustralnih obreda kakvima se, pretvorbom nagonske znatiželje u razumnu želju za mudrošću, i Lucije riješio životinjske metamorfoze i dosegao obnovljenu ljudskost, okončava se mističnim sjedinjenjem s Polijom, mješavinom Beatrice i Laure, alegorijom svekolikoga znanja (usp. Carver 2007: 183-235; Gabriele 2010; Ariani 2010).

35 U prvome licu kao i njegov neposredni eruditski uzor, Hypnerotomachia Poliphili, Caviceov roman oponaša Colonnin pripovijedanjem sna, zapletom ljubavne potrage te opširnim digresijama o arhitekturi, arheologiji, neoplatoničkom nauku, prirodnoj filozofiji, premoći klasične kulture nad autorovom suvremenošću, a pripovijeda o pustolovnim putovanjima po Maloj Aziji i Grčkoj, ali i o dvama onostranim putovanjima - u Had i na Elizejska polja - u snu (usp. Griffin 1986). U lukijanističkom duhu, cijeli roman pripovijeda sjena već pokojnog pripovjedača te se u priči pojavljuju i Boccacciova i Scipionova sjena (usp. i Roush 2015: 118-131), za što i u Dantea, Petrarke i samoga Boccaccia postoje prethodni primjeri i izvan lukijanizma (usp. Roush 2015). O mnoštvu komičnih elemenata Griffin primjećuje da možda i nisu hotimični (usp. Griffin 1986: 133) - što donekle podsjeća na čitateljski dojam o Vetranovićevu spjevu. - Posve slučajno, i Lukijanov opus obuhvaća satiričku pripovijest o kiničkome filozofu Peregrinu. No važnost podudarnosti s Vetranovićevim naslovom i epomnimnim likom ne treba preuveličavati, jer je posrijedi veoma čest leksem, npr. u nazivu nekoliko talijanskih književnih akademija (Accademia dei Pellegrini / Peregrini, Accademia Peregrina), od kojih su prve polovicom 16. stoljeća bile osnovane u Veneciji i Parmi (usp. N. Tarchiani, Giuseppe Gabrieli, Adelmo Damerini, članak "Accademia" u Enciclopedia Treccani, http://www.treccani.it/ enciclopedia/accademia_\%28Enciclopedia-Italiana\%29). 
čivši tu i publiku, dobro je poznavao Apulejev roman (usp. ibid.: 51), pa ne treba sumnjati da ga je pomno čitao i Držićev stariji prijatelj Vetranović. Osobito je značajno da se Držić - po svoj prilici potaknut lukijanističkim strujanjima u renesansnoj Italiji, kao i vlastitim sklonostima - ne libi navodno platonističko štivo gotovo do neprepoznatljivosti, ali minuciozno parodirati u službi društvene satire, što Vetranoviću zacijelo nije promaknulo. Nema dvojbe ni da su obojica pratila i renesansne odjeke romana, kako neoplatoničko-mistične, tako i komično-prijestupničke, bliže shvaćanju da je Zlatni magarac i "izvorno" parodija (platonizirane) Homerove Odiseje (usp. Clarke 1995: 42; Harrison 2000: 220 i passim; Carver 2007: 392-393), a navodno misterijska 11. knjiga, gdje Lucije pristupa Izidinu kultu, sofistička satira religije i tobožnjega izlaska iz Platonove špilje (usp. Harrison 2000: 251, 254 i d.). Da su Vetranoviću bila itekako bliska Držićeva književna i umjetnička iskustva, pokazuju neobične podudarnosti između teksta Piligrina i podjednako nedovršenog, alegorijskog, ali i parodično-satiričnog spjeva metamorfičke motivike talijanskoga autora s kojim hrvatska književna povijest Vetranovića, za razliku od Držića slijedom studija Frana Čale, nikad nije povezivala: riječ je o Magarcu $(1517)^{36}$ s bezvjerja ozloglašenoga Niccolòa Machiavellia.

Iz Apulejeva romana mnoge pojedinosti Piligrina Vetranović crpi uglavnom izravno, no i kroz sugestije talijanskih posrednika u pogledu nekih kulturno posvećenih tema (osobito fortune i prirode, rasprave o čovjekovu položaju, nadmoći klasičnih uzora) i alegorijskih toposa (poput metamorfoze, onostranog putovanja, prizivanja mrtvih, vilinsko-mitološkog imaginarija, spoznajno-lustralnog simbolizma vode). Kako je metamorfički eklekticizam predloška uzor i hrvatskome kao i europskim oponašateljima, postupci premještanja i preobrazbe u Piligrinu odgovaraju Albertievoj i uopće anticiceronijanskoj tehnici mozaičnosti, odnosno Terencijevu načelu contaminatio, kojega se pridržava i Machiavelli (usp. Najemy 1993: 74). Već spominjani prizor u kojemu satir liječi magarca od obijesti premlaćujući ga po mojemučinu savjetu najočitije priziva sve batine bez broja što ih Lucije podnosi prije i pogotovo nakon zlosretne pretvorbe u magarca (usp. osobito Apulej 1997: 60-61, 126-128, 131-133, 161-162 itd.); neposredno prije, nemilosrdne "muhe lajnene" $(P$ 3371), nastale iz zlatnih mrava $(P$ 3244-

36 Kao nerijetko o Piligrinu, i o Machiavellievu Magarcu u ozbiljnih se kritičara nađe strogih sudova: "Iako njegova koncepcija ima Machiavellievu karakterističnu smionost i ekscentričnost, struktura mu je labava i arhaična, izvedba neuobičajeno slaba" (Dionisotti 1993: 43). 
3245), ${ }^{37}$ koje majmunica dozove da tovara napadnu i izbodu do krvi ( $P$ 3356) sve dok se ovaj ne strovali - a napomenimo da stih "po tleh se uprosti kako sve mrtva stvar" ( $P$ 3354) parafrazira završnicu Danteova razgovora s Francescom: "i padoh ko što mrtvo tijelo pada" (Pakao V 142) - ima prethodnika u Apulejevoj priči o mravima koji do smrti izgrizu roba premazana medom (usp. Apulej 1997: 147); na kraju Vetranovićeve epizode, zlostavljani se magarac zahvaljuje što se naučio pokornosti ( $P$ 3402-3420) izvukavši isti gorko satirični zaključak kao Lucije. ${ }^{38}$ Okrutne fizičke patnje u Piligrinu i Zlatnome magarcu ne trpe samo protagonisti i magarac u spomenutoj epizodi nego i druga živa bića koja od otrova ili sakaćenja čak umiru, neka u strašnim bolovima (npr. medvjed $P$ 135-160; svraka $P$ 175; rob, Apulej 1997: 147; medvjed Trazileon, ibid.: 171; raskomadani mladić, ibid.: 176; trovačica, 199-200, itd.). Od tjelesnih muka Lucija i Piligrina, kao i likove koji povremeno zrcale njihovu sudbinu, još gore pogađa sram zbog ropskoga položaja te poruge i smijeha kojima su izloženi (usp. P 1281, 1311, 1323, 1622, 1743, 1848, itd.; Apulej 1997: 3, 27, 54, 61, 72, 96-98, 152-153, 199, itd.) pa Piligrin višekratno - kao jednako hudom sudbinom progonjeni Lucije i Psiha - izražava želju da umre ili počini samoubojstvo.

Nasuprot mravima što ubiju roba, "vojska mrava" pritječe u pomoć Psihi (Apulej 1997: 104), kao što progovaraju i u korist protagonista istupaju "trstika", "voda", Jupiterov orao, "toranj" (usp. ibid.: 105, 106), koje oponašaju mnogi Piligrinovi sugovornici od Javora i mojemuče do blavora i štapa. Vetranovićeve zlonamjerne vile i božice dvojnice su Apulejevih čarobnica i vještica, Birene, Fotide, drugih demonskih i pokvarenih žena, podle Psihine svekrve Venere i glumljenih "božica", tj. glumaca koji za vrijeme svečanih igara na pozornici izvode dramatizaciju mitske zgode iz Ovidijevih Pretvorba koja se spominje u Ilijadi, prizor Parisove kobne odluke da zlatnu jabuku dodijeli Veneri kao najljepšoj, a uskratom uvrijedi Junonu i Minervu (usp. Apulej 1997: 200-203). Ta Lucijeva pripovijest pruža idealnu građu za Vetranovićev rad škarama i ljepilom: zlatna jabuka nepredvidljivo mijenja

37 Pretvorbom nastale muhe Piligrin uspoređuje s Erinijama ("jak da je zla srda iz pakla izvrila" $P$ 3246) kao što se u Apuleja muhe (ali i druge životinje čiji oblik poprime demonska čudovišta od kojih treba čuvati ljudsko truplo) prispodobljuju Harpijama (usp. Apulej 1997: 32, 90). Što se tiče mrava razmiljenih Piligrinom, oni su karika metamorfoza između misli, prosa i pčela, a gmižu i po protagonistu (P 115-128), samo ga ne usmrte kao roba u Zlatnome magarcu.

38 "Odlučih se okaniti svake pretvornosti i lukavosti, te ću se prema svojim gospodarima ponašati kao besprijekoran magarac" (Apulej 1997: 62). 
kontekst i funkciju, pa sve više podsjeća na alegoriju hirovitosti Fortune / česti i samovolje moćnika, zbog kojih, kako kaže Lucije dok spoznaje zakone sveopće pretvorbenosti, nema ničega za što bi se moglo pouzdano znati "da je zbilja ono što jest" (Apulej 1997: 19). ${ }^{39}$ Ulogu jabuke u sudu o ljepoti božica zadobiva "cvietak rumeni" ( $P$ 2669), dok Parisov zadatak zapadne Piligrina, samo što on ne bira između triju, nego tobože čak četiriju božica, od kojih bi dvije središnje morale biti jedna te ista (“četiri božice [...] / Junon i Palada, Minerva i Venera”, $P 2433$ i 2435), kao da je brojčanu inovaciju proizveo rad njegova sna.

Česti trenuci u kojima se Piligrin skameni i postane sličan mramoru potječu iz opisa začaranoga grada Hypate i njegovih kamenih kipova ${ }^{40}$ te veličanstvenoga predvorja Birenine kuće, gdje Lucije, između ostaloga, vidi mramorne kipove Pobjede, Dijane i Akteona usred pretvorbe u jelena (usp. Apulej 1997: 20 i d.), koji, križani sa sličnim pretvorbama iz Ovidija i kasnijim inačicama, možda Vetranovića nadahnjuju za pretvorbu djevičanske Dijanine vile u mramoran kip (P 1386-1386), a njezina nesretnog udvarača satira u kladu ( $P$ 1425-1426). Kao i Birenina kuća u Zlatnome magarcu, i u Piligrinu se opisuju perivoj i raskošna vrata Dijanina dvora (usp. $P 970$ i d.), ${ }^{41}$ možda i u dosluhu s ekspanzijom toga motiva u tad već glasovitome Polifilovu snu.

Raspon Apulejevih motiva koje je Vetranović iskoristio za svoj šaroliki spjev znatno je veći nego što je u inačici Zlatnoga magarca poslužio Machiavelliu koji satirični potencijal magareće pretvorbe i njezinu dvosmislenu alegoričnost podvrgava pragmatičnim zasadama vlastite političke

39 Bezazlenome Piligrinu jabuku daruje djevica poluzmajskog tijela kako bi ga čuvala od divljih zvijeri ( $P 795$ i d.), da bi on zatim istom jabukom uzalud pokušao otkupiti svoju slobodu od vile koja ga je zasužnjila (usp. P 914-918), a naknadno otkriva da je u Dijaninu perivoju takvih jabuka bezbroj (P 1021-1024). Ukratko, navodno čarobni predmet ne pomaže Piligrinu da od sebe odvrati nesreću (P 1185-1192) ni da je pokloni vilama pa izbjegne Dijanin sud (P 1771 i d.); one mu održe moralističku bukvicu o tome kako njih ne zanima zlato te ga optuže da ih je htio podmititi, kao da se metaforička čarobna moć zlatne jabuke poništava njezinom materijalnom doslovnošću. U krilu jedne od vila jabuka doista metamorfozira u "klupko od kuka" i podigne oluju ( $P$ 1871-1882). Za tumačenje motiva zlatne jabuke i zmajolike djevice kao preradbe starozavjetnoga motiva kušnje i istočnoga grijeha v. Grmača 2015: 281-282.

40 "U cijelomu gradu nije bilo ničega što bih držao da je zbilja ono što jest: sve je bilo čarolijama pretvoreno u drugi neki lik. Čak i kamenje na koje sam nailazio držao sam za ljude koji su bili pretvoreni u kamen" (Apulej 1997: 19).

${ }^{41} \mathrm{O}$ vratima Kirkine špilje na mjestu gdje se spjev prekida samo se kaže da su zlatna $(P$ 4373-4374); zanimljivo razmatranje o toj pojedinosti v. u Grmača 2015: 288-295. 
teorije te svojemu poimanju čovjekove naravi, kudikamo bližem Albertievu, negoli neoplatonističkom i kršćanskom moralizmu. To je neobičnije - ako ne računamo strast s kojom hrvatski pjesnik prikuplja građu za svoje književne mozaike, usporedivu s Lucijevom neodoljivom radoznalošću prema pretvorbenoj magiji - što Vetranovićev Piligrin ne skriva da se upušta u kontaminaciju s djelom pisca ateističke reputacije i prevrednovateljske smionosti, ${ }^{42}$ počevši od Dubrovčaninove odluke da svojega opasnog učitelja upadljivo oponaša slobodoumno, na rubu parodije, reciklirajući Danteove stihove. Uz središnji pretvorbeni motiv i erotske momente Apulejeva Zlatnog magarca, Machiavelliev kratki Magarac (broji 1091 stih) u tercinama kombinira dakle duhovito konstruirane aluzije i krupne citatne uzorke iz Danteove Komedije, preuzimajući od nje i metar, čime učvršćuje dojam da je njegov Magarac travestija Danteova spjeva i satira njegove pobožnosti te Plutarhov dijalog (koji je referencija i Albertieve kritike mita o ljudskoj nadmoći, usp. Bonazzi 2008) Bruta animalia ratione uti ili Gryllus (usp. Berg 2014/2015: 280-282); popisu treba dodati i šaljive parafraze i citatne umetke najprepoznatljivijih Petrarkinih stihova, u parodičnoj opreci prema revanju (L'Asino I, 9 i 27), kako pripovjedač naziva svoj glas. Kao Lucije i svi njegovi pripovjedni baštinici, junak-pripovjedač najavljuje da će ispričati patnje koje je osobno proživio u magarećem obličju (iako bi se prava metamorfoza mogla dogoditi tek u dijelu teksta koji nedostaje, kod Kirke, kao što se i Piligrin, također u izostalome dijelu spjeva, od Kirke nada postići obratnu pretvorbu u čovjeka); no dok se Lucije u magarca pretvara protiv svoje volje, greškom neuspjele Fotidine vradžbine, Machiavelliev lik dragovoljno će se - po savjetu lijepe Kirkine pastirice (na različite načine izokrenute dvojnice Apulejeve Fotide, Danteova Vergilija - usp. Berg 2014/ 2015: 289 - i Vetranovićeve mojemuče), koja junaka vodi po mračnoj Kirkinoj šumi te mu postaje zanosna ljubavnica i učiteljica - četveronoške kretati skrivajući se u stadu Kirkinom čarolijom poživotinjenih bivših ljudi (usp. L'Asino II 145-147; III 115-123). Poigravajući se prvim pripovjednim licem i analogijama s Danteovim likom-pripovjedačem, koji također sa svojim autorom dijeli životopis i djela, spjev aludira na životne nedaće samoga Machiavellia (usp. King 2008: 282) i na crnu nezahvalnost (L'Asino I 13; III 78) Medičejaca na njegovoj nekadašnjoj odanoj službi i vrijednosti njegova umijeća vojno-političkog savjetnika, na čemu su mu, nakon njegove

42 Za čitanje Machiavellia iz Nietzscheove optike usp. Vacano 2007. 
uloge u propalome republikanskom prevratu, uzvratili zatvorom, mučenjem i uskratom bilo kakve državničke službe. Pritom se, ponovno u skladu s metamorfičkom poetikom spjeva i podjednako metamorfičkom autorovom političkom teorijom, izvješće o njegovim jadima izrazito križa s tužaljkom iz XIII. pjevanja Pakla (usp. King 2007: 293), u kojoj Pier della Vigna pripovijeda kako su ga suparnici na dvoru cara Fridrika II. klevetom natjerali na samoubojstvo, dok njegov sugovornik, Danteov lik, godine 1300, kad se odvija fikcijski susret, još ne može znati da će uskoro i sam postati oklevetani izgnanik poput svojega budućeg parodista. Taj je hibrid također jedan od znakova da je Vetranović Machiavellieva Magarca pozorno čitao jer je Javorova priča o vlastitoj "česti” u Piligrinu podsjeća na oba uzora. Kao oklevetani Danteov carski tajnik i kao sam Dante, neodređena skupina "zlieh ljudi" ( $P$ 288) i njihova "nenavid" $(P$ 320) nanijele su mu nepravdu, izgubio je ljudskost i pretvorio se u stablo što plače i govori (usp. $P$ 291-292). Istovremeno međutim Javorova jadikovka sadržava elemente koji ne potječu iz Komedije, nego iz Machiavellieva Magarca: za nesreću nije kriv on, nego “čes" ( $P$ 321; usp. L'Asino III 79-81); njezino su djelo naopaka vremena što pogoduju oholoj ludosti nauštrb protjeranoga razuma (usp. $P$ 245-246), ona navodi ljude na nezahvalnost i izdaju ${ }^{43}$ te ih pretvara u opake životinje: upravo zbog nje "ljudi se stvaraju u zvieri razlike" $(P 240),{ }^{44}$ a pravednici

43 “Tiem koga nadieli zlosrd'jem čes huda, / taj tuži i cvieli od muke i truda, / i svi ga porazi s nesrećom još sliede / i mili i drazi rane mu povriede" ( $P$ 260).

44 I u Machiavellia i u Vetranovića nailazimo na popise životinja i čudovišno hibridnih bića, zapravo bivših ljudi, na koje će naići oba protagonista, a da će ih vidjeti, uz (uglavnom uzaludno) upozorenje neka pripaze da i njih ne snađe životinjska metamorfoza, obojici najavljuju sugovornici - u Machiavellia lijepa pastirica, u Vetranovića nekoliko savjetnika među kojima je prvi u nizu Javor: "Nu ćeš još na svieti nakazni razlike / očima vidjeti i trude razlike" ( $P$ 347-348). U Vetranovićevu prizoru nesretnog vepra koji se brani pred Dijaninim sudom (o čijim književnim prethodnicima usp. Lupić 2014) mogu se razabrati tragovi ili otisci papaka, prasca čiji govor o nadmoći životinja, koje žive po razumu i u skladu s prirodom, nad slabim, pohlepnim, taštim, samoljubivim, nepoštenim ljudima (koji su "nesretniji od ikoje zemaljske životinje", L'Asino VIII 103-194), opsežno preuzet od Plutarhova prasca Gryllusa (usp. Berg 2014/2015: 284-282), u Machiavellia zauzima posljednje poglavlje prije prekida teksta; taj prasac odbacuje svaku želju da se opet pretvori u čovjeka; u Piligrinu pak, na jednome od popisa metamorfozom stvorenih životinja, nailazimo na još jednoga prasca, ovaj put srodnijega Machiavellievu i Plutarhovu jer (zajedno s konjem i mazgovom) ustraje u svojem životinjskom položaju (samo što se ne razabire jasno je li tu pripovjedačevo izvješće moralističko ili satirično): "Sam prasac od gore, jaki sve gnusan stvor, / strpjeti ne more razložni odgovor; / i s prascem konj pastuh i mazak pritili / ne htješe prignut duh da ih razlog primili; / objesni ner tako meu zviermi gdje stahu, / i vrlo i opako kopiti prucahu; / a prasac hrocaše od tuge i jada, / za-č svasma ne znaše, 
odlaze u progonstvo služiti i mučiti se "po tudjoj državi" (P 265). ${ }^{45}$ Javor zvuči očajno, ali je kadar grohotom se smijati medvjedovoj tegobi s nadutim trbuhom (P 134-13) i Piligrinovoj ludosti (usp. $P$ 100-104) pokazujući cinizam za kakav se, pogotovo u Vetranovićevo protureformacijsko doba, optužuje prokazani autor renesansnoga Magarca. Možda baš zato upravo Javor dijeli i Machiavellievu mudrost o sveopćoj pretvorbenosti svijeta, ${ }^{46}$ koju junak Magarca - jer je i on, poput praznoglavoga Piligrina, "oskudne pameti”, zbog čega svoj stid iskazuje jednim od komičnijih pastiša analognih mjesta u Dantea i Petrarke (usp. L'Asino II 85-90) - doznaje od svoje spasiteljice, vodilje i seksualno-političke instruktorice, Kirkine službenice: povijesni i politički događaji nisu dio nekog svrhovitog providnosnog nauma,

što je razlog i pravda, / i što je višnji sud i tko ga ne obsluži, / koliko plačan trud s njime se sadruži, / kad vajmeh smrt prieka naglo se pripravi, / grešnoga človjeka ter s duhom rastavi”" (P 361-372).

45 Politički termin spominje i Piligrin, moleći bogove da ga "nastane u mirnoj državi” ( $P$ 332), ne samo zato što je Machiavelli politički filozof, nego zato što i protagonist Magarca razglaba o djelovanju fortune na političke prilike u antičkoj povijesti te pouku o seksualnoj hrabrosti koju je primio od lijepe djevojke tumači kao alegoriju poziva čovjeku da se ne odaje dokolici, pasivnosti i ispraznim vjerskim obredima, nego da bude (politički), kako se danas voli reći, proaktivan (usp. L'Asino V 28-127). Javorov politički aluzivni govor o naopakosti suvremenoga svijeta (usp. $P 219$ i dalje) vjerojatno se nadahnjuje i odlomcima Magarca u kojima lik-pripovjedač izlaže razloge svoje trenutne nesreće, ali i VIII. poglavljem, u kojemu prasac nabraja poroke koji ljude čine slabijima od životinja.

46 Filozofski razgovor o razlozima neprestane mijene i metamorfičnosti prirode svojim pitanjem pokreće Piligrin, služeći se probavom kao metaforom: "I rekoh: javore, molim te vajmeh sad, / kako toj bit more, reci mi boga rad? / U svako jur doba dano je naravi, / što prima utroba, da se toj probavi, / i što se probavlja, veće se nikadar / opet ne ponavlja u svoju predjnju stvar" ( $P$ 211-216). Iako se većina Javorova odgovora doima kao opis poraznoga trenutnog stanja svijeta, on ipak, tragom Magarca, nastoji nagovijestiti kako su priroda i društvene prilike ciklične: "dano je naravi, / da obsluži razlog svoj, da obsluži drum pravi" (P 217-218), pod pretpostavkom da sintagma "drum pravi", iako podrijetlom iz Dantea, barem dvosmisleno priziva i zakonitost i redovitost prirodne mijene, upravo kao u Machiavellievu spjevu riječ "providnost" (usp. L'Asino III 118; v. Berg 2014/2015: 296). (Dodala bih da to vrijedi, upravo kao u Nietzschea, za motiv "bolesti” mladića iz hipodijegetskog umetka u Magarcu, od koje ga otac pokušava izliječiti; no njegova tobožnja bolest zapravo je strast za trčanjem otvorenim prostorima, želja za slobodom i samostalnošću. Moramo primijetiti da je taj motiv možda nadahnuo Piligrinovu "boljezan", $P$ 86, zbog koje je krenuo na put u snu.) Od protagonistova iskaza u Magarcu kako se neće žaliti na svoju sreću, nego će joj se prepustiti (usp. L'Asino IV 10-12) Javor preuzima savjet Piligrinu: "Strpjen'je tiem spravljaj ter tvoje sve zgode / s naliepom probavljaj, kako kad prihode" ( $P$ 349-350), ali sam veli da će dalje tugovati nad svojom sudbinom i preobrazbom. I mojemuča, iako s mnogo proturječja i bez suvisla ishoda, junaka poziva da bude spreman djelovati kad kucne pravi čas ("Pripravno tiem stani, kad pride vrieme toj, / ter misli sve shrani, ke prospe u kril tvoj” (P 207-208). 
nego posljedica nestalnosti Fortune, no upravo je njezina prevrtljivost razlog za optimizam jer, kako će iz drugih razloga tvrditi Gundulić, na svijetu nema ničega osim mijene (usp. L'Asino III 85-93; V 31-36; VIII 133-135, itd.), kako se opširno obrazlaže u Vladaru (usp. Machiavelli 1985: 142-143). Zato joj se i čovjek - umjesto da se samo zdvaja i trpi, poput Lucija, Javora i Piligrina, udarcima sreće treba okrenuti suho lice, bez ijedne suze (usp. L'Asino III 86-87) - mora hrabro prilagođavati, pače pretvarati se (i u smislu himbe i u smislu metamorfoze), tj. pritajiti svoju ljudsku narav, da bi lakše podnio nepovoljna razdoblja, dok čeka da se prilike poprave i osvane trenutak za ljudsko djelovanje. ${ }^{47} \mathrm{U}$ tu svrhu dakle ne samo da u životinjskoj pretvorbi nema ničega nužno lošeg (kad mijeni, tj. pretvorbi, podliježe sve, pa i pojam pretvorbe), nego je štoviše uputno da čovjek, ne čekajući da ga poživotinji neka viša sila u liku Kirke, sam izabere životinjski lik u koji će preobraziti i svoju ljudsku prirodu (tj. koji će oponašati u djelovanju), ${ }^{48}$ a to je u ovom slučaju prijetvorno ponizni magarac; naime priroda i jest stalna mijena, pretvorba i kontaminacija, pa ne postoji nikakva odjelita ljudska priroda, kao što su odavno nagovijestili Lukijan i Alberti, kao i (prijetvorni platonist) Apulej.

Postoji li "drum pravi" kojim bi se krenulo po Machiavellievu Magarcu i po Vetranovićevu Piligrinu oduvijek je bila, a vjerojatno će i ostati,

47 "Da zaključim: ako se sreća mijenja, a ljudi uporno ostaju pri svojoj naravi, sretni su dok se to dvoje slaže; no čim se prestanu slagati, nesretni su. Ja pak smatram da je bolje biti naprasit nego obziran; jer sreća je žena, pa je moraš tući i krotiti; i vidi se kako se ona prije pokorava naprasitima nego obzirnima koji u svemu postupaju hladno. Sreća je, kako rekosmo, žena, pa je uvijek prijateljica mladih ljudi jer su bezobzirniji, žešći i s više joj smjelosti zapovijedaju" (Machiavelli 1985: 143). Na podlozi ove slavne pouke iz Vladara, postaje izglednija pretpostavka da je Piligrin, koji poput Lucija krotko podnosi da ga zlostavljaju zle žene i zna samo kukati, satiričan lik.

48 Kako upozoravaju tumači koji Magarca čitaju usporedno s Vladarom (npr. Ferroni 1974; King 2007; Viroli 2010: 127), vladar se - dakle i čovjek, a osobito pisac - mora ugledati na kentaura, razvijajući Picova "kameleona" u posve antiplatoničkom smjeru: "Morate dakle znati da postoje dva načina borbe: zakonima i silom. Prvi je način svojstven čovjeku, drugi životinjama; no kako prvi način često puta nije dovoljan, valja se utjecati i drugome. Stoga je nužno da se vladar zna dobro poslužiti i ljudskim i životinjskim svojstvima. Vladare su tome prikriveno poučavali stari pisci, koji navode kako su Ahilej i mnogi drugi drevni junaci bili predani na odgoj kentauru Hironu, da ih on drži pod svojom stegom. Imati za učitelja poluživotinju i polučovjeka, ne znači ništa drugo doli to da se vladar mora znati poslužiti i jednom i drugom naravi; a služi li se jednom bez druge, nema mu duga vijeka. / Kad je već vladaru nužno da se služi životinjskim svojstvima, mora između njih izabrati lisicu i lava, jer se lav ne može braniti od mreže, a lisica od vukova. Mora dakle biti lisica, hoće li da predosjeti mrežu, a lav da prepadne vukove" (Machiavelli 1985: 129, XVIII. poglavlje). 
zagonetka za tumače i talijanskoga i hrvatskoga pisca. Nedavni rad Stevena Berga (2014/2015) temeljito obrazlaže dosad najdosljedniju analizu Machiavellieve alegorije koju prenosim u šturim crtama: šuma poživotinjenih ljudi, prema Bergu, predstavlja degradirani politički život pod teokratskom represijom, jer kršćanske institucije i svećenstvo - koje Berg prepoznaje u Kirki - njegove sudionike nadziru, ugnjetavaju, lišavaju slobode i samostalnosti, oduzimajući im dostojanstvo i muškost, tjerajući ih na licemjernu poniznost i gramzivu računicu, obezvređujući pojam političkoga života i podređujući ga vlastitom utjecaju; ukinuvši svjetovnu političku sposobnost građana kakva se njegovala u starome Rimu, tj. onemogućujući im da slobodno istupaju i djeluju u državnim pitanjima, teokracija je ljudsko društvo izručila na milost i nemilost fortuni, tj. slučaju (usp. ibid.: 292). Drevna politička vrlina do te je mjere odumrla da jedini izvor znanja ostaje antička filozofija - historiografija i politička misao Tita Livija i Ksenofonta - koju Berg smatra alegorijski personificiranom u Kirkinoj pastirici; no i trenutna vladavina Crkve-Kirke ugrožava i njezin opstanak (usp. ibid.: 292-293) jer ni ona, filozofija, jedina koja pritječe upomoć političkome čovjeku, ne može svojega štićenika izvesti iz carstva gospodarice kojoj je primorana služiti, teologije; može ga ipak održati na životu vodeći s njim ljubav na skrovitu mjestu, učeći ga dakle da se skloni pred Kirkinim neprijateljstvom i uživa u ljubavi prema znanju (usp. ibid.: 294). Kob će se jednom promijeniti, ali se dotad filozof - ljubavnik mudrosti mora pritajiti u magarećem liku; priroda hoće da čovječanstvo opstane i proživi sretnije dane, oslobodivši se prevlasti teologije (usp. ibid.: 296). Protagonist filozofiju ljubi jednako snažno kao i Dante, pa izjavljuje kako bi za nju bio spreman proći i kroz vrata pakla (usp. L'Asino IV 7-9); no njegov odnos prema lijepoj ženi-filozofiji nije isključivo duhovne, nego tjelesne naravi, pa se ni njegov put ne može odvijati po kršćanskoj onostranosti kao Danteov (usp. Berg 2014/2015: 298). ${ }^{49}$

Iako se nipošto ne može tvrditi da je ovdje sažeto Bergovo tumačenje Machiavellieva Magarca kao filozofsko-političke alegorije “točno”, ne može

49 Prema Bergovu alegorijskom tumačenju Plutarhom nadahnuti prasac koji ne želi povratiti ljudskost predstavlja zadovoljnog, lijenog i nadasve apolitičnog podanika Crkve i moralističke stege kojom kršćane drži u pokornosti i krivnji, pa se dakle Machiavelli satirično ograđuje od Plutarhove teze i priklanja Aristotelovu učenju o umu kao čovjekovu distinktivnom svojstvu (usp. Berg 2014/2015: 308-320). Međutim Bergov posljednji zaključak, kao i cijela analiza, premalo pozornosti obraćaju na metamorfozu kao element alegorije. 
mu se odreći stanovita uvjerljivost pokrijepljena pomnim čitanjem. Ne znamo ni je li išta od toga na približno sličan način pročitao i Vetranović ni što ga je, osim kolekcionarstva, ponukalo da zagrabi u Machiavelliev tekst, upiše tragove štiva u svoj spjev i k tome ga prekine na istome mjestu kao i Machiavelli, pa ne znamo ni kakvu je zapravo alegorijsku ulogu namijenio Kirki (a kamoli je li pritom ciljao na Crkvu) ni što bi se dogodilo da je napokon prodro u Kirkin dvor. No barem možemo nagađati kako je možda, po uzoru na Machiavellieva protagonista, na kraju svojevoljno prihvatio nakaradnu metamorfičku masku kao znamen hibridnosti političke i ideološke satire.

\section{LITERATURA}

Acocella, Mariantonietta. 2001. L'Asino d'oro nel Rinascimento: Dai volgarizzamenti alle raffigurazioni pittoriche, Ravenna: Longo.

Adorno, Theodor W. 2002. Aesthetic Theory, priredili Gretel Adorno i Rolf Tiedemann, preveo i priredio Robert Hullot-Kentor, London - New York: Continuum.

Alberti, Leon Battista. 1998. Le intercenali, prijevod i uvod Ida Garghella, Napoli: Edizioni Scientifiche italiane.

Alberti, Leon Battista. 2010. Opere Latine, priredio Roberto Cardini, Roma: Istituto Poligrafico e Zecca dello Stato.

Apulej, Lucije. 1991. O Sokratovu bogu, prijevod, komentari i pogovor Darko Novaković, Split: Logos.

Apulej, Lucije. 1997. Zlatni magarac, prevela Viktorija Bauer, Zagreb: Cid.

Ariani, Marco. 2010. Il sogno filosofico, u Colonna 2010: XXXI-CIX.

Ariosto, Ludovico. 1997. Orlando furioso e Cinque canti, ur. Remo Ceserani i Segio Zatti, Torino: UTET.

Arnaudo, Marco. 2003. Il bestiario di Machiavelli, tra emblematica e naturalismo, "Italica", LXXX, 3, str. 313-333.

Ascoli, Albert Russell i Victoria Kahn (ur.). 1993. Machiavelli and the Discourse of Literature, Ithaca and London: Cornell University Press.

Augustin, Sv. Aurelije. 1973. Ispovijesti, prev. Stjepan Hosu, Zagreb: Kršćanska sadašnjost.

Bahtin, Mihail. 1967. Problemi poetike Dostojevskog, na srpski prevela Milica Nikolić, Beograd: Nolit.

Bahtin, Mihail. 1984a. Problems of Dostoevsky's Poetics, na engl. prev. Caryl Emerson, Minneapolis - London: University of Minnesota Press.

Bahtin, Mihail. 1984b. Rabelais and His World (1965), prevela Hélène Iswolsky, Bloomington: Indiana UP.

Batušić, Nikola i Dunja Fališevac (ur.). 2008. Putovima kanonizacije. Zbornik radova o Marinu Držiću (1508-2008), Zagreb: HAZU. 
Berg, Steven. 2014/2015. Ancients and Moderns under the Empire of Circe: Machiavelli's The Ass, Translation and Commentary. Part Two: Commentary, "Interpretation: A Journal of Political Philosophy”, Double Issue: XL, 1-2, str. 279-311.

Berni, Francesco. 2001. Rime, priredila Silvia Longhi, u Poeti del Cinquecento, tomo I, Poeti lirici, burleschi, satirici e didascalici, izdanje uredili Guglielmo Gorni, Massimo Danzi i Silvia Longhi, Milano-Napoli: Riccardo Ricciardi Editore ("La letteratura italiana. Storia e testi”, XXIII, 1), str. 625-890.

Bertini, Ferruccio. 2009. La favola latina da Fedro al mondo moderno, "Nova Tellvs" XXVII, 1, str. 19-40.

Bonazzi, Nicola. 2008. "Animale irrequieto e impazientissimo": naturalismo e moralità in Alberti, Machiavelli e Bruno, "Annali d'Italianistica, XXVI, Humanisms, Posthumanisms, \& Neohumanisms”, str. 155-170.

Borsetto, Luciana. 2000. Figure Proteja u šesnaestom stoljeću. Metamorfoze morskog proroka u Petrića, Sannazzara i Tassa, "Prilozi" 51-52, str. 59-76.

Borsetto, Luciana. 2002. Riscrivere gli Antichi, riscrivere $i$ Moderni, e altri studi di letteratura italiana e comparata tra Quattro e Ottocento, Alessandria: Edizioni dell'Orso.

Boschetto, Luca. 1995. Democrito e la fisiologia della follia. La parodia della filosofia e della medicina nel Momus di Leon Battista Alberti, "Rinascimento" II, 35 str. 3-29.

Branham, R. Bracht. 1989. Unruly Eloquence: Lucian and the Comedy of Traditions, Cambridge, Massachusetts - London, England: Harvard University Press.

Candido, Igor. 2016. Boccaccio sulla via del romanzo. Metamorfosi di un genere tra antico e moderno, "ArNovIt", 1, str. 8-28.

Cardini, Roberto (1990) Mosaici. Il "nemico" dell' Alberti, Roma: Bulzoni.

Carver, Robert H. F. 2007. The Protean Ass: The Metamorphoses of Apuleius from Antiquity to the Renaissance, Oxford - New York: Oxford University Press Inc.

Castelli, Patrizia. 2002. Bestialità, allegoria, tassonomia nel tramonto del rinascimento, "Bruniana \& Campanelliana", VIII, 1, str. 47-83.

Catanorchi, Olivia. 2003. Luciano, Alberti e Bruno. Note su alcune linee di ricerca, "Annali della Scuola Normale Superiore di Pisa. Classe di Lettere e Filosofia", serija IV, Sv. VIII, 1/2, str. 31-52.

Cerbo, Anna. 2002. Sub specie animalium: uomini e demonio nella poesia di Campanella e Tasso, "Bruniana \& Campanelliana", VIII, 1, str. 85-111.

Ceron, Annalisa. 2015. Leon Battista Alberti's Care of the Self as Medicine of the Mind: A First Glance at Theogenius, Profugiorum ab erumna libri III, and Two Related Intercenales, "Journal of Early Modern Studies", IV, 2, str. 9-36.

Clarke, Bruce. 1995. Allegories of Writing: The Subject of Metamorphosis, Albany: State University of New York Press.

Colonna, Francesco. 2010. Hypnerotomachia Poliphili, Tomo Secondo: introduzione, traduzione e commento, priredili Marco Ariani i Mino Gabriele, Adelphi.

Čale Feldman, Lada. 2016. Omakalina psiha, u Komparativna povijest hrvatske književnosti. Zbornik radova XVIII. Fantastika: problem zbilje, uredile Cvijeta Pavlović, Vinka Glunčić-Bužančić i Andrea Meyer-Fraatz, Split: Književni krug i 
Zagreb: Odsjek za komparativnu književnost Filozofskoga fakulteta Sveučilišta u Zagrebu, str. 42-57.

D'Amico, John. 1984. The Progress of Renaissance Latin Prose: The Case of Apuleianism, "Renaissance Quarterly", XXXVII, 3, str. 351-392.

Dante Alighieri. 1976. Božanstvena komedija, prev. Mihovil Kombol i Mate Maras, u Djela, II, prir. Frano Čale i Mate Zorić, Zagreb: Sveučilišna naklada Liber - Nakladni zavod Matice hrvatske.

Di Grado, Antonio. 1997. L'ombra del camaleonte: il Momus di L. B. Alberti, u Id., Dissimulazioni. Alberti, Bartoli, Tempio, Caltanissetta-Roma: Salvatore Sciascia editore, str. 11.

Dionisotti, Carlo. 1993. Machiavelli, Man of Letters, prevela Olivia Holmes, u AscoliKahn (ur.) 1993: 17-51.

Di Stefano, Elisabetta. 2000. L'altro sapere. Bello, Arte, Immagine in Leon Battista Alberti, Palermo: Centro Internazionale Studi di Estetica.

Di Stefano, Elisabetta. 2011. Leon Battista Alberti e la poetica della contemplazione, u Vie solitaire, vie civile. L'humanisme de Pétrarque à Alberti. Actes du XLVIIe Colloque International d'Études Humanistes, Tours, 28 juin - 2 juillet 2004, uredili Frank La Brasca i Christian Trottmann, Paris: Honoré Champion Éditeur, str. 447-463.

Doglio, Maria Luisa. 1983. Metamorfosi, simbolo e favola. Per una lettura delle "Stanze" del Poliziano, "Italianistica: Rivista di letteratura italiana", XII, 2/3, str. 197-216.

Erazmo Roterdamski. 2015. [1941], The Praise of Folly. 2015. [1941], prev. Hoyt Hopewell Hudson, Princeton and Oxford: Princeton University Press.

Fališevac, Dunja. 1989. Elementi grotesknog i fantastičnog u Vetranovićevu Pelegrinu, u Id., Stari pisci hrvatski i njihove poetike, Zagreb: Hrvatska sveučilišna naklada, str. 96-107.

Fališevac, Dunja. 1997. Kaliopin vrt. Studije o hrvatskoj epici, Split: Književni krug.

Fališevac, Dunja. 2007. Dubrovnik - otvoreni i zatvoreni grad : studije o dubrovačkoj književnoj kulturi, Zagreb: Naklada Ljevak.

Fališevac, Dunja. 2010. Tema bijega u staroj dubrovačkoj književnosti, u Dani Hvarskog kazališta. Putovanje, lutanje i bijeg u hrvatskoj književnosti i kazalištu, Zagreb Split, str. 11-46.

Ferroni, Giulio. 1974. Appunti sull'Asino di Machiavelli, u Letteratura e critica. Studi in onore di Natalino Sapegno, Roma: Bulzoni, str. 313-345.

Gabriele, Mino. 2010. Il viaggio dell'anima, u Colonna 2010: IX-XXX.

Gaisser Haig, Julia. 2008. The Fortunes of Apuleius and the 'Golden Ass' : A Study in Transmission and Reception, Princeton, NJ: Princeton University Press.

Garin, Eugenio (priredio). 1952. Prosatori latini del Quattrocento, Milano-Napoli: Ricciardi.

Garin, Eugenio. 1966. Storia della filosofia italiana, Sv. I, Torino: Einaudi.

Garin, Eugenio. 2005. [1954] Medioevo e Rinascimento. Studi e ricerche, Roma-Bari: Laterza.

Geri, Lorenzo. 2011. A colloquio con Luciano di Samosata. Leon Battista Alberti, Giovanni Pontano ed Erasmo da Rotterdam, Roma: Bulzoni. 
Giorgio Stabile. 1982. La ruota della fortuna: tempo ciclico e ricorso storico, u: Scienze credenze occulte livelli di cultura. Convegno internazionale di studi, Firenze: Olschki, str. 477-503.

Gollnick, James. 1999. The Religious Dreamworld of Apuleius' Metamorphoses: Recovering a Forgotten Hermeneutic, Toronto: Wilfrid Laurier University Press.

Griffin, Clive. 1986. Giacomo Caviceo's 'Libro del Peregrino': the Fate of an Italian Wanderer in Spain, u Book Production and Letters in the Western European Renaissance: Essays in Honor of Conor Fahy, ur. Anna Laura Lepschy, John Took i Dennis E. Rhodes, London: Modern Humanities Research Association, str. 132-146.

Grmača, Dolores. 2010. Držićevi grijesi u tri prizora, u Marin Držić: 1508-2008. Zbornik radova s međunarodnog znanstvenog skupa održanog 5-7. studenoga 2008. u Zagrebu, ur. Nikola Batušić i Dunja Fališevac, Zagreb: Hrvatska akademija znanosti i umjetnosti, str. 247-279.

Grmača, Dolores. 2013. Body Trouble: The Impact of Deguileville's Allegory of Human Life on Croatian Renaissance Literature, u The Pèlerinage Allegories of Guillaume de Deguileville: Authority, Tradition, and Influence, ur. Marco Nievergelt i Stephanie A. Viereck Gibbs Kamath, Cambridge: Boydell \& Brewer, str. 189-208.

Grmača, Dolores. 2015. Nevolje s tijelom. Alegorija putovanja od Bunića do Barakovića, Zagreb: Matica Hrvatska.

Harrison, Stephen J. 2000. Apuleius: A Latin Sophist, Oxford: Oxford University Press. Hatzantonis, Emmanuel. 1960. Il potere metamorfico di Circe quale motivo satirico in Machiavelli, Gelli e Bruno, "Italica", XXXVII, 4, str. 257-267.

King, Ed. 2008. Machiavelli's L'Asino: Troubled Centaur into Conscious Ass, "Canadian Journal of Political Science / Revue canadienne de science politique”, XLI, 2, str. 279-301.

Košuta, Leo. 2008. [1961/1982] Siena u životu i djelu Marina Držića, prevela Suzana Glavaš, u Putovima kanonizacije. Zbornik radova o Marinu Držiću (1508-2008), ur. Nikola Batušić i Dunja Fališevac, Zagreb: HAZU, str. 220-262.

Košuta, Leo. 2008. [1964/1968] Pravi i obrnuti svijet u Držićevu Dundu Maroju, u Putovima kanonizacije. Zbornik radova o Marinu Držiću (1508-2008), ur. Nikola Batušić i Dunja Fališevac, Zagreb: HAZU, str. 263-303.

Kravar, Zoran. 1980-1981. Emblematika Vetranovićeva Pelegrina, "Filologija" 10, str. 315-324.

Kristeller, Paul Oskar. 1962. La tradizione aristotelica nel Rinascimento, Padova: Antenore.

Kristeller, Paul Oskar. 1998. [1990] Il pensiero e le arti nel Rinascimento, na tal. prevela Maria Baiocchi, Roma: Donzelli.

Lamberton, Robert. 1986. Homer the Theologian. Neoplatonist Allegorical Reading and the Growth of the Epic Tradition, Berkeley - Los Angeles - London: University of California Press.

Lollini, Massimo. 2008. Humanisms, Posthumanisms, and Neohumanisms. Introductory Essay, "Annali d'Italianistica" 26, str. 13-33.

Lukijan iz Samozate. 2002. Djela, prevela i priredila Marina Bricko, Zagreb: Matica hrvatska. 
Lukijan iz Samozate. 2002a. Svjetonazori na dražbi, preveo i priredio Pavel Gregorić, Zagreb: Kruzak.

Lupić, Ivan. 2014. Piligrinov otpor, u Otpor. Subverzivne prakse u hrvatskome jeziku, književnosti i kulturi. Zbornik radova 42. seminara Zagrebačke slavističke škole, uredili Tatjana Pišković i Tvrtko Vuković, Zagreb: Zagrebačka slavistička škola, str. 35-79.

Machiavelli, Niccolò. 1971. L'Asino, u Tutte le opere, ur. Mario Martelli, Firenze: Sansoni, str. 954-976.

Machiavelli, Niccolò. 1985. Vladar, preveo Ivo Frangeš, u Niccolò Machiavelli, Izabrano djelo. Prvi svezak, izabrao i priredio Damir Grubiša, Zagreb: Globus, str. 97-147.

Marsh, David. 1998. Lucian and the Latins. Humor and Humanism in the Early Renaissance, Ann Arbor: University of Michigan Press.

Marsh, David. 2003. Aesop and the humanist apologue, "Renaissance Studies" XVII, 1: Bonae Litterae: Current Research on the "Studia Humanitatis", str. 9-26

Medini, Milorad. 1902. Povjest hrvatske književnosti u Dalmaciji i Dubrovniku. Knjiga I, XVI. stoljeće, Zagreb: Matica hrvatska.

Medini, Milorad. 1909. Pjesme Mavra Vetranovića i Marina Držića. Prilozi za poznavanje starije dubrovačke književnosti, "Rad JAZU”, 176, str. 135-161.

Najemy, John M. 1993. Machiavelli and Geta: Men of Letters, u Ascoli - Kahn (ur.) 1993: 53-80.

Najemy, John M. 2014. Machiavelli and History, "Renaissance Quarterly” LVII, 4, str. 1131-1164.

Panizza, Letizia A. 1991. Stoic psychotherapy in the Middle Ages and Renaissance: Petrarch's De remediis, u Atoms, Pneuma, and Tranquillity: Epicurean and Stoic Themes in European Thought, ur. Margaret J. Osler, Cambridge: Cambridge University Press, str. 39-66.

Pavličić, Pavao. 2007. Zabrane u motivacijskom sustavu Vetranovićeva Pelegrina, u Dani Hvarskog kazališta. Građa i rasprave o hrvatskoj književnosti i kazalištu 33. Prešućeno, zabranjeno, izazovno u hrvatskoj književnosti i kazalištu, ur. Nikola Batušić et al., Zagreb - Split: HAZU - Književni krug, str. 5-18.

Petrarca, Francesco. 1987. Moja tajna, izbor i prijevod Frano Čale, Zagreb: Zora.

Pico della Mirandola, Giovanni. 1994. Commento sopra una canzone d' amore, priredio Paolo De Angelis, Palermo: Novecento.

Pico della Mirandola, Giovanni. 1998. Govor o dostojanstvu čovjekovu / Oratio de hominis dignitate, s latinskoga preveo, izvornik priredio, uvod i bilješke napisao Sinan Gudžević, Zagreb: Nova stvarnost.

Pico della Mirandola, Giovanni. 2003. Discorso sulla dignità dell' uomo, priredio Francesco Bausi, Parma: Fondazione P. Bembo, Guanda.

Quondam, Amedeo. 2010. Forma del vivere: l' etica del gentiluomo e i moralisti italiani, Bologna: Il mulino.

Rafolt, Leo. 2009. Čovjek, biljka, životinja: logika slučaja i koncepti groteske i nakaznosti u Vetranovićevu alegorijsko-peregrinacijskom epu, u Id., Drugo lice drugosti. Književnoantropološke studije, Zagreb: Disput, str. 159-194. 
Reale, Giovanni i Dario Antiseri. 2008a. [1983] Storia della filosofia dalle origini a oggi. Vol. 2. Dal Cinismo al Neoplatonismo, Milano: Bompiani.

Reale, Giovanni i Dario Antiseri. 2008b [1983] Storia della filosofia dalle origini a oggi. Vol. 4. Umanesimo, Rinascimento e rivoluzione scientifica, Milano: Bompiani.

Roush, Sherry. 2016. Speaking Spirits: Ventriloquizing the Dead in Renaissance Italy, Toronto - Buffalo - London: University of Toronto Press.

Santoro, Mario. 1989. Ariosto e il Rinascimento, Napoli: Liguori.

Segre, Cesare. 1966. Esperienze ariostesche, Pisa: Nistri Lischi.

Šimić, Krešimir. 2017. Remeta: Studije o Mavru Vetranoviću, Zagreb: Matica hrvatska.

Šundalić, Zlata. 2009. Značenje i funkcija životinja u Držićevim komedijama, u Dani hvarskog kazališta, 35: Nazbilj i nahvao: etičke suprotnosti u hrvatskoj književnosti $i$ kazalištu od Marina Držića do današnjih dana. U čast 500-obljetnice rođenja Marina Držića, ur. Nikola Batušić, Rafo Bogišić, Pavao Pavličić, Milan Moguš, Zagreb-Split: HAZU i Književni krug Split, str. 174-232.

Švelec, Franjo. 1959. Mavro Vetranović. A. Pjesnik u svome vremenu, "Radovi Instituta JAZU u Zadru", Sv. 4-5, Zagreb, str. 127-214.

Švelec, Franjo. 1960. Mavro Vetranović. B. Književni rad, "Radovi Instituta JAZU u Zadru", Sv. 6-7, Zagreb, str. 319-392.

Tate, J. 1929. Plato and Allegorical Interpretation, "The Classical Quarterly" XXIII, 3-4, str. 142-154.

Vacano, Diego A. von. 2007. The Art of Power: Machiavelli, Nietzsche, and the Making of Aesthetic Political Theory, Lanham - Boulder - New York - Toronto - Plymouth UK: Lexington Books.

Vetranović Čavčić, Mavro. 1872. Pelegrin (u tekstu: P), u: Djela. Dio 2: Pjesni razlike. Pelegrin. Drame, Stari pisci hrvatski, priredili Vatroslav Jagić, Ivan August Kaznačić, Đuro Daničić, Zagreb: JAZU, str. 80-196.

Viroli, Maurizio. 2010. Machiavelli's God, na engl. preveo Antony Shugaar, Princeton and Oxford: Princeton University Press.

Yarnall, Judith. 1994. Transformations of Circe: The History of an Enchanteress, Urbana: University of Illinois Press.

Zatti, Sergio. 1989. Il cosmo, la corte, il poema: il sistema delle 'corrispondenze' nel Furioso, "Italianistica: Rivista di letteratura italiana” XVIII, 2/3, str. 367-393. 


\section{SUMMARY}

\section{‘A MOST MIRACULOUS MIRACLE' AND 'DIFFERENT KINDS OF BEASTS': A CONTRIBUTION TO CRITICAL PILGRIMAGES THROUGH MAVRO VETRANOVIĆ'S PILIGRIN}

Drawing on several studies which Dunja Fališevac has dedicated to the unfinished allegorical poem Piligrin ('Pilgrim'), written by the Croatian $16^{\text {th }}$ century poet Mavro Vetranović Čavčić, the paper examines the possibility to view the poem not only within the serious literary tradition of religious and Platonic allegory, but also from the hypothetical perspective of its double-coded disposition, focusing namely on the text's simultaneous affiliation with the opposite, playful generic and thematic lineage, marked, above all, by the Renaissance renewal of Lucian's and Apuleius' legacy. Therefore, I argue that the range of the Italian models to which Croatian literary historians have so far related the Piligrin should be revised in the light of this alternative point of view. I propose to envisage the debt of the Croatian poem to the oeuvre of one of the authors who notably contributed to the flourishing of the Menippean satire and the so-called Lucianism in 15th century Italy, Leon Battista Alberti, an important forerunner of Ariosto's and Machiavelli's satirical developments. The hybridity and the mosaic technique which characterize Vetranović's textual strategies, as well as the poem's emphasis on the subjects of metamorphosis and travel into transcendent worlds, are here ascribed to the poet's propensity for the Anti-Cicerionian humanists, to his interest in comic and satire, and partly to his friendship with the playwright Marin Držić. Since Lucianic themes and narrative modes are intertwined with the double Renaissance reception of Apuleius' Metamorphoses (The Golden Ass), the Piligrin is compared to Apuleius' novel and to one of its most original Italian heirs, Machiavelli's short narrative poem L'Asino (The Ass, 1517). The outcomes of this analysis support the contention about the presence of previously unnoticed resonances of the latter two texts in Vetranović's poem.

Keywords: Vetranović's Piligrin, Dante's Commedia, Neoplatonism and the moralistic reading of Homer and Ovid, Lucian of Samosata, Leon Battista Alberti, AntiCiceronianism, Erasmus of Rotterdam, Ariosto, Poliziano, Apuleius' Metamorphoses or The Golden Ass, L'Asino by Niccolò Machiavelli, metamorphosis, allegory, parody, Menippean satire, pastiche, travesty 